\title{
Morphology, ultrastructure and molecular phylogeny of Wangodinium sinense gen. et sp. nov. (Gymnodiniales, Dinophyceae) and revisiting of Gymnodinium dorsalisulcum and Gymnodinium impudicum
}

\author{
Luo Zhaohe ${ }^{1}$, Hu Zhangxi ${ }^{2}$, Tang Yingzhong ${ }^{2}$, Mertens Kenneth ${ }^{3}$, Leaw Chui Pin ${ }^{4}$, Lim Po Teen ${ }^{4}$, \\ Teng Sing Tung ${ }^{5}$, Wang Lei ${ }^{1}$, Gu Haifeng ${ }^{1}$
}

\footnotetext{
${ }^{1}$ Third Institute of Oceanography; SOA; Xiamen 361005 ,China

${ }^{2}$ CAS Key Laboratory of Marine Ecology and Environmental Sciences; Institute of Oceanology;, Chinese Academy of Science; Qingdao 266071 China

${ }^{3}$ Ifremer, LER BO; Station de Biologie Marine; Place de la Croix, BP40537 F-29185 Concarneau

Cedex ,France

${ }^{4}$ Bachok Marine Research Station; Institute of Ocean and Earth Sciences; University of Malaya; 16310

Bachok, Kelantan, Malaysia

${ }^{5}$ Faculty of Resource Science and Technology; Universiti Malaysia Sarawak; 94300 Kota Samarahan, Sarawak Universiti Malaysia Sarawak; Malaysia
}

\begin{abstract}
:
The genus Gymnodinium includes many morphologically similar species, but molecular phylogenies show that it is polyphyletic. Eight strains of Gymnodinium impudicum, Gymnodinium dorsalisulcum and a novel Gymnodinium-like species from Chinese and Malaysian waters and the Mediterranean Sea were established. All of these strains were examined with LM, SEM and TEM. SSU, LSU and internal transcribed spacers rDNA sequences were obtained. A new genus, Wangodinium, was erected to incorporate strains with a loop-shaped apical structure complex (ASC) comprising two rows of amphiesmal vesicles, here referred to as a new type of ASC. The chloroplasts of Wangodinium sinense are enveloped by two membranes. Pigment analysis shows that peridinin is the main accessory pigment in W. sinense. Wangodinium differs from other genera mainly in its unique ASC, and additionally differs from Gymnodinium in the absence of nuclear chambers, and from Lepidodinium in the absence of Chl $b$ and nuclear chambers. New morphological information was provided for $G$. dorsalisulcum and $G$. impudicum, e.g., a short sulcal intrusion in G. dorsalisulcum; nuclear chambers in G. impudicum and $G$. dorsalisulcum; and a chloroplast enveloped by two membranes in G. impudicum. Molecular phylogeny was inferred using maximum likelihood and Bayesian inference with independent SSU and LSU rDNA sequences. Our results support the classification of Wangodinium within the Gymnodiniales sensu stricto clade and it is close to Lepidodinium. Our results also support the close relationship among $G$. dorsalisulcum, G. impudicum and Barrufeta. Further research is needed to assign these Gymnodinium species to Barrufeta or to erect new genera.
\end{abstract}

Keywords: Key index words, apical structure complex, cyst, dinoflagellate, Lepidodinium, nuclear chambers, pigment, pyrenoid, ultrastructure 
Abbreviations: AIC, Akaike information criterion; ASC, apical structure complex; AV, amphiesmal vesicles; BI, Bayesian inference; BPP, Bayesian posterior probabilities; BS, bootstrap support; DAPI, 4',6-diamidino-2-phenylindole dihydrochloride; DMF, N, N-dimethylformamide; GTR, general time-reversible; MCMC, Markov chain Monte Carlo; ML, maximum likelihood; Mv-chl $a$, monovinyl chlorophyll $a$; NFC, nuclear fibrous connector; RAxML, Randomized Axelerated Maximum Likelihood; Tchl $a$, total chlorophyll $a$

Introduction

Many athecate dinoflagellates have been classified in the genus Gymnodinium, which originally encompassed gymnodinioid species with a cingulum displacement less than $20 \%$ of the cell length (Kofoid and Swezy 1921). Later work put more emphasis on the systematic significance of the apical groove (Takayama 1985). The systematic importance of ultrastructure was understood later, leading to the emendation of the genus Gymnodinium as characterized by (1) a horseshoe-shaped apical groove running in an anticlockwise direction, (2) a nuclear envelope with vesicular chambers, and (3) a nuclear or dorsal fibrous connector (NFC; Daugbjerg et al. 2000). Consequently, Gymnodinium species with a straight apical groove were either transferred to Karenia or Karlodinium, or transferred to Akashiwo when This article is protected by copyright. All rights reserved. 
possessing a clockwise apical groove (Daugbjerg et al. 2000). Later, the genus Takayama was erected to incorporate Gymnodinium species with a sigmoid apical groove (de Salas et al. 2003).

The reclassification of other Gymnodinium species has continued and has accentuated the importance of the shape of the apical groove. For example, Gymnodinium fusus (=Gyrodinium falcatum) was transferred to Ceratoperidinium due to its circular apical groove (Reñé et al. 2013) and later to Pseliodinium (Gómez 2018), and Gyrodinium resplendens was transferred to Barrufeta since it has a Smurf-cap shaped apical groove (Gu et al. 2015a). Other genera were erected to incorporate Gymnodinium-like species where other morphological criteria are considered important. Paragymnodinium is characterized by several nematocysts and absence of an apical groove (Kang et al. 2010), Gyrodiniellum by a loop-shaped row of five elongated amphiesmal vesicles and several nematocysts (Kang et al. 2011), Levanderina by a sulcus with an inner tube containing the longitudinal flagellum and an outer, open furrow (Moestrup et al. 2014), and Pellucidodinium by a semicircular apical groove and nuclear chambers (Onuma et al. 2015).

Erection of a new genus may also be based on differing evolutionary characteristics, e.g., Gymnodinium chlorophorum was transferred to Lepidodinium since its chloroplast is of chlorophyte origin (Hansen et al. 2007); Gymnodinium amphidinioides was transferred to Nusuttodinium because it is characterized by kleptoplastidy (Takano et al. 2014);

This article is protected by copyright. All rights reserved. 
Gymnodinium limneticum and Gymnodinium palustre were transferred to Spiniferodinium because they exhibit capsoid cells as predominant life stage (Kretschmann et al. 2015), and Gymnoxanthella was erected because it is a symbiont of polycystine radiolarians (Yuasa et al. 2016).

In molecular phylogenies, the Gymnodiniales sensu stricto clade encompasses Gymnodinium as well as other genera, e.g., Barrufeta, Dissodinium, Gyrodiniellum, Lepidodinium, Nematodinium, Paragymnodinium, Polykrikos, Spiniferodinium, and Warnowia (Hoppenrath and Leander 2007, Hoppenrath et al. 2009, Kang et al. 2010, Hansen and Daugbjerg 2011, Kang et al. 2011). These genera have apical grooves similar to that of Gymnodinium, with the exception of Warnowia which has an apical groove spiral with 1.5-2.0 turns (Hoppenrath et al. 2009) and Paragymnodinium which does not have an apical groove (Kang et al. 2010). After the separation of Barrufeta, Gyrodiniellum, Lepidodinium, and Paragymnodinium, the genus Gymnodinium remains polyphyletic and the closest relative of the type species, G. fuscum, is unclear (Kretschmann et al. 2015, Wang et al. 2017), suggesting that further subdivisions are needed.

Moestrup et al. (2014) proposed the new term apical structure complex (ASC) that combines the apical groove and the amphiesmal vesicles surrounding the apex. They revealed that the ASC comprises three rows of elongated vesicles in Levanderina fissa. Three rows of vesicles have been reported in other gymnodinioid species, such as Gymnodinium impudicum

This article is protected by copyright. All rights reserved. 
and Barrufeta resplendens (Sampedro et al. 2011, Gu et al. 2015a). Another type of ASC comprises one row of amphiesmal vesicles, as reported in Gyrodiniellum shiwhaense (Kang et al. 2011). The discovery of other types of ASCs can be expected since details of the ASC in most athecate dinoflagellates have not been carefully examined.

Ultrastructural features of Gymnodinium species (e.g., nuclear chambers and nuclear fibrous connector, are sometimes absent; G. litoralis; Reñé et al. 2011). In contrast, Polykrikos and Lepidodinium exhibit nuclear chambers and a nuclear fibrous connector (Bradbury et al. 1983, Hansen et al. 2007, Hoppenrath and Leander 2007). Other criteria may be useful to reclassify Gymnodinium-like species. For instance, Polykrikos lebouriae and Lepidodinium have chloroplasts with a double envelope, and chloroplasts of Lepidodinium even contain Chl $b$ (Watanabe et al. 1990, Elbrächter and Schnepf 1996, Hoppenrath and Leander 2007), and such criteria can be used to differentiate these genera from

\section{Gymnodinium.}

Among the 2000 extant dinoflagellate species that have currently been described, around $15 \%$ of them are known to produce resting cysts (Head 1996). The cyst morphology of Gymnodinium is known to be variable, especially the shape and wall texture. Cysts of $G$. catenatum and related species are brown with a microreticulate wall (Gu et al. 2013) and cysts of G. fuscum have ridges arranged in a hexagonal pattern (Hansen et al. 2000b), but cysts with a smooth surface are more common in species of Gymnodinium, as reported for $G$.

This article is protected by copyright. All rights reserved. 
aureolum, G. impudicum, and G. corollarium (Kobayashi et al. 2001, Tang et al. 2008, Sundström et al. 2009). Cyst morphology can be helpful to differentiate species with similar motile stage morphologies (Gu et al. 2013).

Thessen et al. (2012) reported after an extensive literature review that there are 268 extant Gymnodinium species, with 103 (38\%) never again recorded since their initial descriptions. Only a small fraction of those Gymnodinium species were examined in detail using contemporary methods (e.g., SEM and DNA sequencing). For most species, ultrastructural information is not available. For instance, the ultrastructure of Gymnodinium dorsalisulcum and G. impudicum have not been studied; they are close to Lepidodinium and Barrufeta in terms of molecular phylogeny (Murray et al. 2007, Gu et al. 2015a), suggesting that they are not true Gymnodinium.

Here, the morpho-molecular and ultrastructural characterization of G. dorsalisulcum and G. impudicum are reported from Chinese and Malaysian waters and the Mediterranean Sea. A previously undescribed gymnodinioid species, that is widely distributed in Chinese waters, is reported as well, and assigned to a new genus based on morphological observations and molecular phylogenetic analyses.

This article is protected by copyright. All rights reserved. 


\section{MATERIAL AND METHODS}

\section{Sample collection and treatment}

Surface sediment samples were collected at three sites of Chinese coast and one site in Corsica, Mediterranean Sea from 2010 to 2016 using a grab sampler (Table 1). The sediment samples were stored in the dark at $4{ }^{\circ} \mathrm{C}$ until further treatment. Approximately $5 \mathrm{~g}$ of wet sediment were mixed with $20 \mathrm{~mL}$ of filtered seawater and sonicated for $2 \mathrm{~min}$ (100 watts) to dislodge detrital particles. The watery slurry was incubated directly in series of small containers in f/2-Si medium (Guillard and Ryther 1962 ) at $20^{\circ} \mathrm{C}, 90 \mu \mathrm{mol}$ photons $\cdot \mathrm{m}^{-2} \cdot \mathrm{s}^{-1}$ under a 12:12 h light:dark cycle (hereafter called "standard culture conditions"). Single Gymnodinium-like cells were isolated by means of drawn-out Pasteur pipettes with an AE30 inverted microscope (Motic, Xiamen, China) and established into clonal cultures. Three strains of Wangodinium sinense gen. et sp. nov. and one strain of Gymnodinium impudicum were established from cysts (Table 1).

Macroalgae and sands were collected from the seabed via scuba diving near Sanya,

China and Perhentian island, Malaysia from 2014 to 2017 and deposited into bottles containing seawater collected at the same location. The samples were stirred vigorously to detach the epibenthic cells and the suspension settled in a composite settling chamber. The settled materials were rinsed with filtered seawater and transferred into a polycarbonate bottle. Single Gymnodinium-like cells were isolated from this material and three strains of Gymnodinium dorsalisulcum were established (Table 1). A single Gymnodinium-like cell was

This article is protected by copyright. All rights reserved. 
isolated from a plankton bloom sample collected in Bohai Sea in 2016 and one strain of Gymnodinium impudicum was established (Table 1). Surface sand was collected from intertidal zone during low tide at Damai beach, Kuching, Malaysia in 2015. Samples were stored in a $50 \mathrm{~mL}$ centrifuge tube and single cells were isolated from this material. One strain of Barrufeta bravensis was successfully established (Table 1). All strains were maintained under standard culture conditions.

\section{Light microscopy (LM)}

Vegetative cells were examined with a Zeiss Axio Imager microscope (Carl Zeiss, Göttingen, Germany) equipped with both differential interference illumination and epifluorescence. Light micrographs were obtained using a Zeiss Axiocam HRc digital camera. Approximately $1 \mathrm{~mL}$ of live, healthy culture in mid exponential growth phase was transferred to a $1.5 \mathrm{~mL}$ microcentrifuge tube, and DAPI (4',6-diamidino-2-phenylindole dihydrochloride) stain (Sigma-Aldrich, St. Louis, MO, USA) was added at a final concentration of $10 \mu \mathrm{g} \cdot \mathrm{mL}^{-1}$. The cells were viewed and photographed through a Zeiss Filter set (emission: BP 365-445; beam splitter: FT 395). Chloroplast autofluorescence was observed on live cells using a Leica DM6000B fluorescence microscope (Leica Microsystems, Wetzlar, Germany) equipped with a B/G/R filter cube (blue: emission filter BP420/30, dichromatic mirror 415, suppression filter BP465/20; green: BP495/15, 510, BP530/30; red: BP570/20, 590, BP640/40), and digitally photographed using a Leica 
DFC300 FX digital camera. Cells in mid exponential growth phase were fixed with Lugol's solution at a final concentration of 5\%, and cell size was measured at 400× magnification.

\section{Scanning electron microscopy (SEM)}

Mid-exponential batch cultures $(600 \mu \mathrm{L})$ were fixed for $1 \mathrm{~h}$ at $4{ }^{\circ} \mathrm{C}$ with $4 \% \mathrm{OsO}_{4}(200 \mu \mathrm{L})$ prepared with filtered seawater. The material was then dehydrated in an ethanol series (once in $10,30,50,70$ and $90 \%$, followed by three times in 100\%; 10 min at each step), critical point dried (K850 Critical Point Dryer, Quorum/Emitech, West Sussex, UK), sputter-coated with gold, and examined using a Zeiss Sigma FE (Carl Zeiss Inc., Oberkochen, Germany) scanning electron microscope.

\section{Transmission electron microscopy (TEM)}

Mid-exponential batch cultures were fixed in glutaraldehyde (at a final concentration of $2.5 \%$ ) in $0.1 \mathrm{M} \mathrm{PBS}, \mathrm{pH} 7.4$, for $1 \mathrm{~h}$, concentrated by centrifugation and then washed three times with the same PBS for 10 min each. They were post-fixed in $1 \% \mathrm{OsO}_{4}$ overnight at 4 ${ }^{\circ} \mathrm{C}$ and washed three times with the same PBS for 10 min each. Cells were then dehydrated through a graded ethanol series $(10,30,50,70,95,100 \%)$ for 10 min each. The pellet was embedded in Spurr's resin (Spurr 1969) and sectioned with a Reichert Ultracut E microtome (Leica, Vienna, Austria), mounted on Formvar coated grids, stained with uranyl acetate and lead citrate, and observed with a JEOL JEM-100 transmission electron microscope (JEOL, Tokyo, Japan).

This article is protected by copyright. All rights reserved. 


\section{Pigment analysis}

Twenty mL of two strains of Wangodinium sinense (GBH03) and Gymnodinium dorsalisulcum (TIO09) culture was filtered onto a $25 \mathrm{~mm}$ diameter Whatman GF/F filter (Whatman International Ltd., Kent, UK) under gentle vacuum $(<100 \mathrm{mmHg})$. The filter was then soaked in $1 \mathrm{~mL} \mathrm{~N}, \mathrm{~N}$-dimethylformamide (DMF) and extracted in a freezer $\left(-20^{\circ} \mathrm{C}\right)$ in the dark for $1 \mathrm{~h}$. Whatman GF/F filters of $13 \mathrm{~mm}$ diameter (Swinnex ${ }^{\circledR}$ filter holder) were used to clean the debris in the extractions. The filtrate was mixed with ammonium acetate solution $\left(1 \mathrm{~mol} \cdot \mathrm{L}^{-1}\right)$ in equal proportion. $200 \mu \mathrm{L}$ of the mixture was injected into a Shimadzu LC20A-DAD HPLC system fitted with a $3.5 \mu \mathrm{m}$ Eclipse XDB $\mathrm{C}_{8}$ column $(100 \times 4.6 \mathrm{~mm}$; Agilent Technologies). The gradient elution was performed according to the standard method (Zapata et al. 2000). Pigment quantification was confirmed using standards manufactured by the Danish Hydraulic Institute Water and Environment (DHI), Hørsholm, Denmark.

\section{Molecular phylogenetic analyses}

Single cells were isolated and washed three times with sterilized bi-distillate water and were used as the template to amplify about $1430 \mathrm{bp}$ of the LSU rDNA (D1-D6 domains) using the primers D1R (forward, 5'-ACCCGCTGAATTTAAGCATA-3') (Scholin et al. 1994), 28-1483R (reverse, 5'-GCTACTACCACCAAGATCTGC-3') (Daugbjerg et al. 2000), 1740 bp of the SSU rDNA, using the primers SR1 (forward,

5'-TACCTGGTTGATCCTGCCAG-3') and SR12b (reverse, 5'-CGGAAACCTTGTTACGACTTCTCC-3'; Takano and Horiguchi 2006), and 600 bp of

This article is protected by copyright. All rights reserved. 
the total ITS, using the primers ITSA (forward, 5'-CCTCGTAAC

AAGGHTCCGTAGGT-3'), ITSB (reverse, 5'-CAGATGCTTAARTTCAGCRGG; Adachi et al. 1996). For each ribosomal DNA amplification, a $50 \mu \mathrm{L}$ PCR cocktail containing $0.2 \mu \mathrm{M}$ forward and reverse primer, PCR buffer, $50 \mu \mathrm{M}$ dNTP, $1 \mathrm{U}$ of Taq DNA polymerase (Takara, Dalian, China) was subjected to 35 cycles using a Mastercycler PCR (Eppendorf, Hamburg, Germany). The PCR protocol was identical to that of Gu et al. (2015b). PCR products were sequenced directly in both directions using the ABI Big-Dye dye-terminator technique (Applied Biosystems, Foster City, CA, USA), according to the manufacturer's recommendations. New sequences were deposited in GenBank with accession numbers from MH732671 to MH732694.

Newly obtained LSU and SSU rDNA sequences were incorporated into those of closely related species available in the GenBank and that of outgroup taxa were first aligned using MAFFT v7.110 (Katoh and Standley 2013) online program (http://mafft.cbrc.jp/alignment/server/) with default settings. Alignments were manually checked with BioEdit v. 7.0.5 (Hall 1999). The program jModelTest (Posada 2008) was used to select the most appropriate model of molecular evolution with Akaike information criterion (AIC). This test chose the general time-reversible (GTR) model of substitution (Rodriguez et al. 1990) following a gamma distribution shape parameter (0.4330 for LSU rDNA and 0.2280 for SSU rDNA; GTR+ G). Maximum likelihood (ML) analyses were conducted with RaxML v7.2.6 (Stamatakis 2008) on the T-REX web server (Boc et al. 2012) using the model GTR+G. Node support was assessed with 1000 bootstrap replicates. This article is protected by copyright. All rights reserved. 
A Bayesian reconstruction of the data matrix was performed with MrBayes 3.0b4

(Ronquist and Huelsenbeck 2003) using the best-fitting substitution model (GTR + G). Four

Markov chain Monte Carlo (MCMC) chains ran for five million generations, sampling every 1000 generations, with an appropriate burnin (10\%), as inferred from the evaluation of the trace files using Tracer v1.5 (http://tree.bio.ed.ac.uk/software/tracer/). A majority rule consensus tree was created in order to examine the posterior probabilities of each clade.

\section{RESULTS}

\section{Morphology and ultrastructure}

Wangodinium Z.Luo, Zhangxi Hu, Yingzhong Tang \& H.F.Gu gen. nov.

\section{Diagnosis}

Dinoflagellate with amphiesmal vesicles arranged in horizontal rows. The apex is surrounded by two rows of narrow elongated amphiesmal vesicles (AVs) in a loop shape. A furrow extends ventrally from the cingulum to near the apex. Sulcus is deeply depressed and extends to near the antapex, comprising of ca. 20 AVs. Nuclear envelope chambers and nuclear fibrous connector (NFC) absent. Cells possess one reticulated chloroplast enveloped by two membranes with terminal pyrenoids. Cells possess chlorophyll $c 2$ and $c 3$. The major carotenoid is peridinin and cells also contain antheraxanthin, $\beta, \beta$-carotene and diadinoxanthin. Ocelloid, nematocyst, taeniocyst, pusule system, eyespot, peduncle absent. Trichocyst present. It differs from Lepidodinium in the absence of Chl $b$ and nuclear 
chambers. It differs from Barrufeta and Gymnodinium litoralis in the number of rows of narrow elongated AVs that surround the apex.

Type species. Wangodinium sinense Z.Luo, Zhangxi Hu, Yingzhong Tang \& H.F.Gu sp. nov.

Etymology. 'Wangodinium' honors the Chinese protozoologist Jiaji Wang (also spelled as Chia Chi Wang), who achieved the first investigation on protozoa in Xiamen Harbor in 1932. The suffix '-dinium', meaning 'vortex' is commonly applied to dinoflagellates.

Wangodinium sinense Z.Luo, Zhangxi Hu, Yingzhong Tang \& H.F.Gu sp. nov. (Figs. 1-4)

\section{Description}

Cell shape is ovoid. The epicone is rounded to conical and equal in size to the hypocone. The ventral ridge on the right side of the epicone is pronounced and deflected to the left. The hypocone is rounded with a more projected right lobe. The cingulum is wide, narrow, descending with a displacement of approximately two cingular widths. The sulcus is deeply depressed and extends to near the antapex and extends as a narrow furrow to contact the apical structure complex (ASC). Living cells are 12.5-17.5 $\mu \mathrm{m}$ long and 10.0-13.8 $\mu \mathrm{m}$ wide. Nucleus is spherical, and located in the anterior side of the cell. The amphiesmal vesicles are arranged in $15-17$ horizontal rows; 5-6 rows on the epicone, 5 rows on the cingulum, and 5-6 rows on the hypocone. The sulcus has 4-5 rows of vesicles. The ASC is loop-shaped and contains two rows of 6-7 narrow elongated amphiesmal vesicles. The distal end of the ASC

This article is protected by copyright. All rights reserved. 
is $0.5-1.0 \mu \mathrm{m}$ below its starting point. The inner row of ASC bears approximately 50 small knobs. Six or seven irregular amphiesmal vesicles are surrounded by ASC. Cells possess a single reticulate chloroplast in the periphery. They are enveloped by two membranes with terminal pyrenoids. Cells possess chlorophyll $c_{2}$ and $c_{3}$. The major carotenoid is peridinin and cells also contain antheraxanthin, $\beta, \beta$-carotene and trace of diadinoxanthin. Cysts are spherical with a diameter of 9.4-13.2 $\mu \mathrm{m}$ and have a smooth surface.

Holotype: SEM stub of strain G27 designated as TIO201801 deposited at Third Institute of Oceanography, State Oceanic Administration, Xiamen 361005, China.

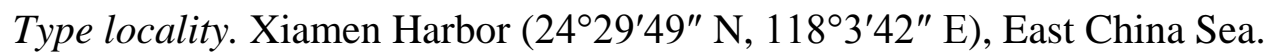

Etymology. 'sinense' refers to the coasts of China where the species was found.

Distribution. East China Sea, South China Sea, Yellow Sea.

GenBank accession number sequences. MH732687 (SSU rDNA), MH732680 (LSU rDNA) and MH732672 (ITS rDNA) of strain G27.

Description. Vegetative cells of Wangodinium sinense strains G27, GLY03 and GBH03 were morphologically indistinguishable (Figs. 1, 2, S1 in the Supporting Information). Cells of strain G27 were ovoid, $12.5-17.5 \mu \mathrm{m}$ long $(14.6 \pm 1.1 \mu \mathrm{m}, \mathrm{n}=50)$ and $10.0-13.8 \mu \mathrm{m}$ wide $(12.1 \pm 1.2 \mu \mathrm{m}, \mathrm{n}=50)$. The epicone was rounded to conical and nearly equal in size to the hypocone (Fig. 1, A and B). The hypocone was rounded and divided into two lobes by the This article is protected by copyright. All rights reserved. 
sulcus with a more projected right lobe (Fig. 1A). One green to golden reticulated chloroplast was located in the periphery of the cell (Fig. 1, A and C). The nucleus was spherical and occupied most part of the epicone (Fig. 1D). Asexual reproduction was through binary fission (Fig. 1B). The cingulum was deeply incised and had sharp edges, descending with a displacement of approximately two cingular widths (Fig. 2A). The sulcus was deeply excavated, and extended as a narrow furrow of around $85 \%$ of the height of the epicone, where it connected to the onset of the apical structure complex (ASC, Figs. 1A, 2A). Cysts formed in culture were spherical with a diameter of 9.4-13.2 $\mu \mathrm{m}(10.9 \pm 0.9 \mu \mathrm{m}, \mathrm{n}=20)$. The cysts were filled with transparent to brown granules and had a smooth surface (Fig. 1, E and F).

The pronounced ventral ridge on the right side of the epicone extended and deflected to the left, thus the cingulum and the sulcus formed a shallow S-shape in ventral view (Figs. 1A, 2A). The cells had 5-6 rows of polygonal amphiesmal vesicles (AVs) on the epicone and hypocone, and 5 rows of rectangular AVs on the cingulum (Fig. 2, B-D). The ASC was loop-shaped, running anticlockwise, and encircled the apex around 80\% (Fig. 2, E and F). The ASC consisted of two rows of AVs (central ridge, CR) with each row comprising 6-7 vesicles (Fig. 2, E and F). The distal end of ASC was $0.5-1.0 \mu \mathrm{m}$ below its starting point. Six or seven irregular AVs were located in the apex and surrounded by the ASC (A1-A7 in Fig. 2, $\mathrm{E}$ and $\mathrm{F}$ ). Around 50 small knobs ornamented the inner central ridge (Figs. 2E, S1C). The sulcus comprised of approximately 20 AVs arranged in 4-5 longitudinal rows (Fig. S1D). A schematic drawing of Wangodinium sinense is presented in Figure 3.

This article is protected by copyright. All rights reserved. 
Longitudinal sections through the cell showed a large nucleus in the epicone, and a reticulate chloroplast in the periphery with terminal pyrenoids (Fig. 4, A and B). The thylakoids were grouped in twos or threes to form lamellae. Several pyrenoids grouped together, each of them was surrounded by a double envelope (Fig. 4, B and C). A rectangular structure $(2.6 \mu \mathrm{m}$ long and $1.2 \mu \mathrm{m}$ wide $)$ enclosing numerous fibrils was enveloped by two membranes (Fig. 4D). The dinokaryon consisted of many condensed chromosomes and a nucleolus. The nuclear membrane was regular and smooth, without the presence of nuclear chambers (Fig. 4E). The amphiesmal vesicles contained a thin plate (Fig. 4F). A pusule system was not observed.

\section{Gymnodinium dorsalisulcum}

Vegetative cells of Gymnodinium dorsalisulcum strain TIO09 from Sanya, China were 28.4-36.1 $\mu \mathrm{m}$ long $(31.6 \pm 2.6 \mu \mathrm{m}, \mathrm{n}=20)$ and $19.7-26.7 \mu \mathrm{m}$ wide $(23.3 \pm 2.1 \mu \mathrm{m}, \mathrm{n}=20)$. Many banded and brown chloroplasts were located in the periphery of the cell and the nucleus was spherical and occupied half of the epicone (Fig. 5, A and B). The epicone was rounded and nearly twice the size of the hypocone, which was rounded as well (Fig. 5A). The cingulum was deeply incised and had sharp edges, with a displacement of approximately two cingular widths (Fig. 5A). The sulcus was narrow and deeply excavated. It extended as a narrow furrow slightly into the epicone and extended deep into the antapex (Fig. 5, A and C). The ASC was loop-shaped and started just above the sulcal intrusion, running anticlockwise, and encircling the apex around 80\% (Fig. 5, C and D). The ASC consisted of three rows of 
vesicles with small knobs ornamented on the outer row (Fig. 5E). Numerous fibrils that originated from small knobs were sometimes observed (Fig. 5F).

Longitudinal sections through the cell showed a large nucleus in the epicone, many chloroplasts in the periphery and two stalked pyrenoids in the middle of the cell (Fig. 6A). The thylakoids were grouped in twos or threes to form lamellae (Fig. 6B). The chloroplasts were enveloped by three membranes. The pyrenoid was surrounded by a starch sheath (Fig. 6C). The amphiesmal vesicles contained a thin plate under which numerous trichocysts and mucocysts were present (Fig. 6D). The cells had two pusule systems each consisting of an elongated and narrow chamber surrounded by numerous pusular vesicles that opened into it (Fig. 6E). The dinokaryon consisted of many condensed chromosomes (Fig. 6A). The nuclear membrane had nuclear chambers and nuclear pores (Fig. 6F).

\section{Gymnodinium impudicum}

The vegetative cells of Gymnodinium impudicum strain TIO251 from Corsica were 13.1-29.8 $\mu \mathrm{m}$ long $(20.1 \pm 4.5 \mu \mathrm{m}, \mathrm{n}=30)$ and $20.0-30.4 \mu \mathrm{m}$ wide $(26.0 \pm 2.8 \mu \mathrm{m}, \mathrm{n}=30)$. They often formed chains with two, four and eight cells (Fig. 7A). Numerous banded chloroplasts were located in the periphery of the cell. The intermediate cells in the chain had a flattened epicone and hypocone, whereas the apical (antapical) cells had a dome-shaped epicone (hypocone) and flattened hypocone (epicone; Fig. 7, A and C). There were round pores in the middle apex and antapex through which the cells form chains (Fig. 7, B and C). The cingulum was

This article is protected by copyright. All rights reserved. 
deeply incised with a displacement of approximately two cingular widths. The sulcus was narrow and deeply excavated. It extended as a narrow furrow of around $1 / 3$ of the height of the epicone, where it connected to the onset of the ASC (Fig. 7D). The ASC was loop-shaped and started just above the sulcal intrusion, running anticlockwise, and encircling about $90 \%$ of the apex (Fig. 7E). The ASC consisted of three rows of vesicles (Fig. 7F). Numerous small knobs were located in the outer row of vesicles (Fig. 7G).

Longitudinal and transverse sections through the cell showed an elongated nucleus in the middle of the cell and many chloroplasts in the periphery (Fig. 8, A and B). The cells had a pusule system consisting of a narrow chamber surrounded by numerous pusular vesicles that opened into it (Fig. 8C). The thylakoids were grouped in twos or threes to form lamellae (Fig. 8D). The chloroplasts were enveloped by two membranes (Fig. 8D). Pyrenoids were not observed. The dinokaryon consisted of many condensed chromosomes and the nuclear membrane had vesicle chambers (Fig. 8E). In the periphery of the cell, two types of extrusomes were present including trichocysts and vesicles with numerous polygonal vesicles (Fig. 8F).

\section{Pigments}

Ten kinds of photosynthetic pigments were detected in the Wangodinium sinense strain GBH03 and Gymnodinium dorsalisulcum strain TIO09 including five kinds of chlorophyll and five kinds of carotenoids (Fig. S2, A and B in the Supporting Information). For strain GBH03, the most abundant chlorophyll was monovinyl chlorophyll $a$ (Mv-chl $a ; 246.72 \mathrm{pg}$ •

This article is protected by copyright. All rights reserved. 
cell $\left.^{-1}\right)$ and pheophorbide $\left(245.80 \mathrm{pg} \cdot\right.$ cell $\left.^{-1}\right)$, followed by chlorophyll $c_{2}\left(74.04 \mathrm{pg} \cdot\right.$ cell $\left.^{-1}\right)$ and trace of chlorophyll $c_{3}\left(6.11 \mathrm{pg} \cdot \operatorname{cell}^{-1}\right)$. The total Chl $a$ concentration (Tchl $a=\mathrm{Mv}-\mathrm{Chl}$ $a+$ pheophorbide) was $492.52 \mathrm{pg} \cdot$ cell $^{-1}$. Peridinin was the most concentrated carotenoid $\left(333.40 \mathrm{pg} \cdot\right.$ cell $\left.^{-1}\right)$ followed by antheraxanthin $\left(81.76 \mathrm{pg} \cdot \mathrm{cell}^{-1}\right)$ and diadinoxanthin $(2.38 \mathrm{pg}$ - cell $^{-1}$ ). There was a similar composition of pigments for strain TIO09, but the concentrations of most pigments were nearly 2-fold higher than the strain GBH03. Monovinyl chlorophyll $a$ $\left(557.06 \mathrm{pg} \cdot \mathrm{cell}^{-1}\right)$ was the most abundant chlorophyll for TIO09 followed by pheophorbide $\left(328.39 \mathrm{pg} \cdot \mathrm{cell}^{-1}\right)$, chlorophyll $c_{2}\left(137.44 \mathrm{pg} \cdot \mathrm{cell}^{-1}\right)$ and trace of chlorophyll $c_{3}(5.61 \mathrm{pg} \cdot$ cell $^{-1}$ ). The total $\mathrm{Chl} a$ concentration was $885.46 \mathrm{pg} \cdot \mathrm{cell}^{-1}$, which was 1.8 -fold higher than strain GBH03. For carotenoids, peridinin $\left(388.65 \mathrm{pg} \cdot \mathrm{cell}^{-1}\right)$ was also the most abundant pigment followed by antheraxanthin $\left(182.61 \mathrm{pg} \cdot \mathrm{cell}^{-1}\right)$ and trace of diatoxanthin $(14.11 \mathrm{pg} \cdot$ cell $\left.^{-1}\right)$. Both strains had little amount of $\beta, \beta$-carotene $\left(17.59 \mathrm{pg} \cdot\right.$ cell $^{-1}$ for GBH03 and 14.02 $\mathrm{pg} \cdot \mathrm{cell}^{-1}$ for TIO09).

\section{Molecular phylogeny}

Chinese strains of Wangodinium sinense shared identical SSU, LSU and ITS rDNA sequences, and they differed from Gymnodinium sp.1 (LSU rDNA, KP790188) from the Mediterranean Sea at 41 positions (92.87\% similarity). Wangodinium sinense differed from Lepidodinium viride at 41 and 96 positions (97.74\%, and $86.85 \%$ similarity) of partial SSU and LSU rDNA sequences. Gymnodinium impudicum strains TIO251 and TIO335 shared identical SSU, LSU and ITS rDNA sequences with the strain from the type locality. Chinese This article is protected by copyright. All rights reserved. 
strains of Gymnodinium dorsalisulcum shared identical SSU, LSU and ITS rDNA sequences and differed from the Australian strain SM28 only at 2 and 1 positions $(99.88 \%$, and $99.87 \%$ similarity) of partial SSU and LSU rDNA sequences, and differed from the Malaysian strain SS10H1 at 0, 3 and 2 positions (100\%, $99.79 \%$ and $99.65 \%$ similarity) of SSU, LSU and ITS rDNA sequences.

Maximum likelihood (ML) and Bayesian inference (BI) generated similar trees (Fig. 9) based on LSU rDNA sequences differing only at a few internal nodes. The well resolved Gymnodiniales sensu stricto clade comprised Gymnodinium as well as other genera like Barrufeta, Polykrikos, Nematodinium, Nusuttodinium, Spiniferodinium, Lepidodinium, Paragymnodinium, Warnowia, Nematodinium, and Gyrodiniellum. Wangodinium sinense and an unidentified Gymnodinium species formed a clade with maximal support (100 BS/1.00 BPP), and a sister clade was formed by Lepidodinium chlorophorum and L. viride with maximal support. These two clades clustered together with strong support (100 BS/0.99 BPP). Gymnodinium impudicum, Gymnodinium dorsalisulcum, Barrufeta bravensis and $B$. resplendens formed a clade with maximal support, which was a sister clade of Wangodinium and Lepidodinium with a moderate ML bootstrap support (90 BS), but a low Bayesian posterior probability $(<0.7 \mathrm{BPP})$.

This article is protected by copyright. All rights reserved. 
Maximum likelihood (ML) and Bayesian inference (BI) generated similar trees (Fig. S3 in the Supporting Information) based on SSU rDNA sequences differing only at a few internal nodes. The well resolved Gymnodiniales sensu stricto clade comprised Gymnodinium as well as other genera like Barrufeta, Polykrikos, Nematodinium, Nusuttodinium, Spiniferodinium, Lepidodinium, Paragymnodinium, Warnowia, Nematodinium, and Gyrodiniellum.

Wangodinium sinense formed a clade with Lepidodinium chlorophorum and $L$. viride with maximal support. Gymnodinium impudicum and G. dorsalisulcum formed a clade with moderate support (100 BS/0.74 BPP), which was a sister clade of Barrufeta resplendens and B. bravensis with strong support (100 BS/0.95 BPP).

\section{DISCUSSION}

\section{Morphology}

A type of ASC consisting of one row of amphiesmal vesicles with numerous small knobs has been reported in Gyrodiniellum shiwhaense (Kang et al. 2011) and refered as type II ASC (Wang et al. 2017). The ASC of Wangodinium sinense consists of two rows of fragmented amphiesmal vesicles with inner vesicles ornamented with small knobs. This type of ASC has not been reported previously, thus it is here designated as a type III ASC. A type I ASC consists of a deep groove surrounded by two pronounced ridges or three elongated vesicles (Wang et al. 2017), commonly found in marine Gymnodinium trapeziforme (Attaran-Fariman et al. 2007), G. aureolum (Tang et al. 2008), G. corollarium (Sundström et al. 2009), G. catenatum and G. microreticulatum (Gu et al. 2013), G. litoralis (Reñé et al. 2011), and G.

This article is protected by copyright. All rights reserved. 
impudicum (Fraga et al. 1995, present study) as well as in the freshwater G. fuscum, G. mirabile, G. obesum (Hansen and Flaim 2007) and G. plasticum (Wang et al. 2017). These vesicles of type I ASC can be ornamented with numerous small knobs (Sampedro et al. 2011, Moestrup et al. 2014, Gu et al. 2015a) or with no small knobs at all (Reñé et al. 2011). Species from closely related genera, e.g., Polykrikos lebouriae (Hoppenrath and Leander 2007), Nematodinium armatum (Takayama 1985), Spiniferodinium limneticum (Kretschmann et al. 2015), Nusuttodinium acidotum (Takano et al. 2014), Barrufeta bravensis, $B$. resplendens, also have a similar ASC (Sampedro et al. 2011, Gu et al. 2015a). However, differences in the shape of ASC have been identified, e.g., a fish-hook shaped ASC in Spiniferodinium limneticum (Kretschmann et al. 2015), and a Smurf-cap shaped ASC in Barrufeta bravensis (Sampedro et al. 2011).Moreover, Wangodinium sinense has a chloroplast surrounded by two membranes in contrast to three in Gymnodinium fuscum, the type species of Gymnodinium (Hansen et al. 2000b). Based on these unusual morphological characters, we erect the new genus Wangodinium to incorporate the strain G27 and related strains.

Under the light microscope, Wangodinium sinense was characterized by a deep sulcal intrusion, a pronounced ventral ridge and a spherical nucleus located in the epicone.

Morphological comparisons of species similar to $W$. sinense are listed in Table 2.

Wangodinium sinense differs from Lepidodinium chlorophorum by possessing a pronounced cingulum overhang and terminal pyrenoids (as opposed to internal pyrenoids; Hansen et al. 2007). Lepidodinium chlorophorum also differs from $W$. sinense by its green colouration This article is protected by copyright. All rights reserved. 
(Elbrächter and Schnepf 1996). Wangodinium sinense is morphologically very close to Gymnodinium aureolum regarding the cell shape, deep sulcal intrusion and a pronounced ventral ridge, but $W$. sinense has a spherical nucleus in the epicone in contrast to an elongated nucleus in the cingular part of G. aureolum (Hansen et al. 2000a, Tang et al. 2008). Moreover, G. aureolum has a pusule and nuclear chambers (Hansen 2001), which W. sinense lacks.

Wangodinium sinense is also very close to Gymnodinium litoralis in cell shape, ventral ridge, sulcal intrusion and the shape and location of nucleus, but differs in the cingulum displacement (two versus three cingulum widths) and presence of pyrenoids in $W$. sinense but not in G. litoralis (Reñé et al. 2011). Moreover, paired cell chains were observed for $G$. litoralis (Reñé et al. 2011) but never for W. sinense. Wangodinium sinense differs from $G$. corollarium in the shape and location of its nucleus. Wangodinium sinense has several pyrenoids, which $G$. corollarium lacks, and a spherical cyst shape, as opposed to an ellipsoidal for G. corollarium (Sundström et al. 2009).

Wangodinium sinense is also similar to Gyrodinium impendens because of a sigmoid sulcus and a pronounced cingulum overhang. However, W. sinense is relatively smaller in size and its length: width ratio is much less. Both species have a spherical nucleus but it is located in the epicone for W. sinense, versus intercingular for G. impendens (Larsen 1996). Detailed information of the ASC in G. impendens is not available so comparison of this 
character is not possible. Wangodinium sinense is also morphological similar to Gyrodinium vorax, but has only half size of $G$. vorax and a displacement of two cingular widths instead of three (Biecheler 1952).

The shape of ASC can be very variable, although the term "horseshoe-shaped" is generally used to describe the ASC in Gymnodinium species. The ASC can also be circular (e.g., Gymnodinium mirabile; Hansen and Flaim 2007), fish-hook shaped (e.g., Spiniferodinium limneticum; Kretschmann et al. 2015), or Smurf-cap shaped (e.g., Barrufeta bravensis; Sampedro et al. 2011). Subtle differences in the shape of ASC were identified in closely related species, such as a closed loop in Polykrikos lebouriae (Hoppenrath and Leander 2007) and an open loop in Polykrikos geminatum (Qiu et al. 2013). Whether these are true Polykrikos is still in debate as the type of Polykrikos has an open loop ASC and lacks a chloroplast (Hoppenrath and Leander 2007). A "horseshoe-shaped" ASC is not only present in the Gymnodiniales sensu stricto clade, but also in phylogenetically distant species such as Grammatodinium tongyeonginumand Levanderina fissa (Moestrup et al. 2014, Li et al. 2017), suggesting that convergent evolution has occurred.

Spherical and smooth cysts were produced by Wangodinium sinense, and have also been reported for Gymnodinium aureolum, G. corollarium, and G. impudicum (Kobayashi et al. 2001, Tang et al. 2008, Sundström et al. 2009). Other species display polygonal reticulations: G. fuscum produces transparent cysts that have ridges arranged in a hexagonal pattern, and $G$. 
catenatum and related species generate brown cysts with microreticulations (Hansen et al. 2000b, Gu et al. 2013). Whether or not cyst morphology is systematically meaningful at species or generic level remains to be determined.

The Gymnodinium dorsalisulcum strains fit the original description in having a posterior girdle with a displacement of two cingulum widths, numerous chloroplasts, and a spherical nucleus in the epicone (Hulburt et al. 1960, as Katodinium dorsalisulcum). This species was described from a culture established via incubating cyst-like cells (Hulburt et al. 1960), suggesting that it has a cyst stage. Pyrenoids have not been reported for the type (Hulburt et al. 1960), but were found in Australian strains (Al-Qassab et al. 2002, Murray et al. 2007) and confirmed here as stalked pyrenoids. The ASC of G. dorsalisulcum was described as originating from the junction of cingulum and sulcus (Murray et al. 2007), but a short sulcal intrusion is here discerned above which the ASC originates. The ASC is characterized by three rows of vesicles whereas the sulcal intrusion does not have such structures.

Gymnodinium dorsalisulcum has been reported in the British West Indies, Australia, and Japan (Hulburt et al. 1960, Al-Qassab et al. 2002, Murray et al. 2007, Hoppenrath et al. 2014), and here its distribution is extended to the South China Sea. Our results support that this is a thermophile species.

This article is protected by copyright. All rights reserved. 
The Gymnodinium impudicum strains fit the original description in producing cell chains and the shape of the apical groove (Fraga et al. 1995). Only the small knobs were detected in the outer lateral vesicles of ASC, but not the small knobs in the inner lateral vesicles as observed by Sampedro et al. (2011). Gymnodinium impudicum was mainly distributed in temperate areas but blooms in the Mediterranean Sea and Bohai Sea in August (Fraga et al. 1995, present study), and in the Seto Inland Sea in July (Iwasaki 1971, Kobayashi et al. 2001), suggesting that $G$. impudicum prefers relatively high temperatures.

The pyrenoid type is variable among the three examined species. Wangodinium sinense and Gymnodinium dorsalisulcum have terminal and stalked pyrenoids respectively, whereas G. impudicum does not have a pyrenoid. Pyrenoids have been regarded to be useful for differentiation only at interspecific level (Schnepf and Elbrächter 1999). Nuclear chambers were not observed in Wangodinium sinense, but these may have not been identified in this study since they are present in G. dorsalisulcum and G. impudicum and many other similar species. Here, NFC was not detected in these three species but this might be because serial sectioning was not performed.

\section{Molecular phylogeny}

Our results support the monophyly of Gymnodiniales sensu stricto clade and the separation of Gymnodinium fuscum from other Gymnodinium species (Kretschmann et al. 2015, Wang et al. 2017), including our new strain G27 and related strains, thus support the idea that they are not true Gymnodinium. An unidentified Gymnodinium species from the Mediterranean Sea

This article is protected by copyright. All rights reserved. 
(as Gymnodinium sp.1; Reñé et al. 2015) is phylogenetically close to Wangodinium sinense, suggesting that it belongs to Wangodinium as well and that this genus has a wider distribution. Unfortunately, morphological details of these Mediterranean strains are not available. The close relationship between Wangodinium and Lepidodinium in the molecular phylogeny suggests that they might be congeneric. However, Lepidodinium is a green dinoflagellate whose chloroplasts contains Chl $b$ but lacks peridinin (Watanabe et al. 1990, Elbrächter and Schnepf 1996), in contrast, Wangodinium has chloroplasts which contains peridinin but lacks $\mathrm{Chl} b$. Lepidodinium possibly replaced the peridinin-containing chloroplast by the chloroplast of a chlorophyte through tertiary endosymbioses (Dorrell and Howe 2015). A chloroplast of chlorophyte origin was only reported in Lepidodinium, and probably in Gymnodinium maguelonnense as well (Biecheler 1952) whose phylogenetic position has not been resolved yet. This kind of replacement by a chlorophyte chloroplast might take place only once in the evolutionary history of dinoflagellate, thus supports the split of Wangodinium who still conserves the peridinin-containing chloroplast from Lepidodinium. The separation of Wangodinium from Gymnodinium and related genera is consistent with their morphological differences as listed in Table 3.

The close relationship among Gymnodinium impudicum, G. dorsalisulcum and Barrufeta has been reported previously (Sampedro et al. 2011, Reñé et al. 2015, Wang et al. 2017) and is supported here. Our results suggest that one (or two) new genus (genera) is needed to incorporate these two Gymnodinium species according to LSU and SSU rDNA sequences based phylogenies. The alternative would be to emend the genus Barrufeta to encompass This article is protected by copyright. All rights reserved. 
these two species. Barrufeta is characterized by an apical structure complex of very elongated transversal loop with the ending point below the starting point (Sampedro et al. 2011), but apical structure complex of Gymnodinium impudicum and G. dorsalisulcum are much shorter with the ending point above the starting point (Fraga et al. 1995, Murray et al. 2007, present study). Small knobs were observed in the lateral vesicles in G. impudicum and $G$. dorsalisulcum compared to the middle vesicles in Barrufeta bravensis and B. resplendens (Sampedro et al. 2011, Gu et al. 2015a). Gymnodinium litoralis also has an elongated apical structure complex with the ending point below the starting point (Reñé et al. 2011), but its morphological similarity with Barrufeta does not mirror in the molecular phylogeny, probably because small knobs are absent in ASC of G. litoralis.

Gymnodinium impudicum and G. dorsalisulcum also differ from Barrufeta in other ultrastructural characters. Presence of nuclear chambers is reported for G. impudicum and G. dorsalisulcum here, but not for B. bravensis and B. resplendens (Sampedro et al. 2011, Gu et al. 2015a). Gymnodinium impudicum is characterized by a chloroplast surrounded by two membranes, unlike most peridinin containing dinoflagellate species which generally have three (Schnepf and Elbrächter 1999), including B. bravensis (H. Gu, pers. obs.). Considering that the morpho-molecular characterization of only a limited number of Gymnodinium species has been done, no nomenclatural changes are proposed at the moment for these two species.

This article is protected by copyright. All rights reserved. 


\section{ACKNOWLEDGEMENTS}

We thank two anonymous reviewers for constructive suggestions that improved the manuscript greatly. This work was supported by the National Natural Science Foundation of China (41676117), the NSFC-Shandong Joint Fund for Marine Ecology and Environmental Sciences (U1606404), and the Scientific and Technological Innovation Project supported by the Qingdao National Laboratory for Marine Science (2016ASKJ02). Research permission was given by Marine Park of Malaysia and fund from MOSTI for sampling in Perhentian Island.

\section{REFERENCES}

Adachi, M., Sako, Y. \& Ishida, Y. 1996. Analysis of Alexandrium (Dinophyceae) species using sequences of the 5.8S ribosomal DNA and internal transcribed spacer regions. $J$. Phycol. 32:424-32.

Al-Qassab, S., Lee, W. J., Murray, S., Simpson, A. G. B. \& Patterson, D. J. 2002. Flagellates from stromatolites and surrounding sediments in Shark Bay, Western Australia. Acta

Protozool. 41:91-144.

This article is protected by copyright. All rights reserved. 
Attaran-Fariman, G., Salas, M. F. D., Negri, A. P. \& Bolch, C. J. S. 2007. Morphology and phylogeny of Gymnodinium trapeziforme sp. nov. (Dinophyceae): a new dinoflagellate from the southeast coast of Iran that forms microreticulate resting cysts. Phycologia 46:644-56.

Biecheler, B. 1952. Recherches sur les Péridiniens. Bull. Biol. Fr. Belgique 36 (Suppl.): $1-149$.

Boc, A., Diallo, A. B. \& Makarenkov, V. 2012. T-REX: a web server for inferring, validating and visualizing phylogenetic trees and networks. Nucleic Acids Res. 40: W573-9.

Bradbury, P. C., Westfall, J. A. \& Townsend, J. 1983. Ultrastructure of the dinoflagellate Polykrikos: II. The nucleus and its connections to the flagellar apparatus. J. Ultrastruct. Res. $85: 24-32$.

Campbell, P. H. 1973. The phytoplankton of Gales Creek with emphasis of the taxonomy and ecology of estuarine phytoflagellates. Ph.D. dissertation, University of North Carolina, Chapel Hill, NC, 354 pp.

This article is protected by copyright. All rights reserved. 
Daugbjerg, N., Hansen, G., Larsen, J. \& Moestrup, Ø. 2000. Phylogeny of some of the major genera of dinoflagellates based on ultrastructure and partial LSU rDNA sequence data, including the erection of three new genera of unarmoured dinoflagellates. Phycologia $39: 302-17$.

De Salas, M. F., Bolch, C. J. S., Botes, L., Nash, G., Wright, S. W. \& Hallegraeff, G. M. 2003. Takayama gen. nov. (Gymnodiniales, Dinophyceae), a new genus of unarmored dinoflagellates with sigmoid apical grooves, including the description of two new species. $J$. Phycol. 39:1233-46.

Dorrell, R. G. \& Howe, C. J. 2015. Integration of plastids with their hosts: Lessons learned from dinoflagellates. Proc. Natl. Acad. Sci. USA 112:10247-54.

Elbrächter, M. \& Schnepf, E. 1996. Gymnodinium chlorophorum, a new, green, bloom-forming dinoflagellate (Gymnodiniales, Dinophyceae) with a vestigial prasinophyte endosymbiont. Phycologia 35:381-93.

Fraga, S., Bravo, I., Delgado, M., Franco, J. M. \& Zapata, M. 1995. Gyrodinium impudicum sp. nov. (Dinophyceae), a non toxic, chain-forming, red tide dinoflagellate. Phycologia $34: 514-21$.

This article is protected by copyright. All rights reserved. 
Gómez, F. 2018. Redefinition of Ceratoperidinium and Pseliodinium (Ceratoperidiniaceae,

Dinophyceae) including reassignment of Gymnodinium fusus, Cochlodinium helix and $C$. pirum to Pseliodinium. CICIMAR Oceánides 33:1-11.

Gu, H., Liu, T., Vale, P. \& Luo, Z. 2013. Morphology, phylogeny and toxin profiles of Gymnodinium inusitatum sp. nov., Gymnodinium catenatum and Gymnodinium microreticulatum (Dinophyceae) from the Yellow Sea, China. Harmful Algae 28:97-107.

Gu, H., Luo, Z., Mertens, K. N., Price, A. M., Turner, R. E. \& Rabalais, N. N. 2015a. Cyst-motile stage relationship, morphology, ultrastructure, and molecular phylogeny of the gymnodinioid dinoflagellate Barrufeta resplendens comb. nov., formerly known as Gyrodinium resplendens, isolated from the Gulf of Mexico. J. Phycol. 51:990-99.

Gu, H., Liu, T. \& Mertens, K.N. 2015b. Cyst-theca relationship and phylogenetic positions of Protoperidinium (Peridiniales, Dinophyceae) species of the sections Conica and Tabulata, with description of Protoperidinium shanghaiense sp. nov." Phycologia 54: 49-66.

This article is protected by copyright. All rights reserved. 
Guillard, R. R. L. \& Ryther, J. H. 1962. Studies of marine planktonic diatoms. I. Cyclotella nana Hustedt and Detonula confervacea Cleve. Can. J. Microbiol. 8:229-39.

Hall, T. A. 1999. BioEdit: a user-friendly biological sequence alignment editor and analysis program for Windows 95/98/NT. Nucleic Acids Symp. Ser. 41:95-98.

Hansen, G. 2001. Ultrastructure of Gymnodinium aureolum (Dinophyceae): toward a further redefinition of Gymnodinium sensu stricto. J. Phycol. 37:612-24.

Hansen, G., Botes, L. \& De Salas, M. 2007. Ultrastructure and large subunit rDNA sequences of Lepidodinium viride reveal a close relationship to Lepidodinium chlorophorum comb. nov. (= Gymnodinium chlorophorum). Phycol. Res. 55:25-41.

Hansen, G. \& Flaim, G. 2007. Dinoflagellates of the Trentino Province, Italy. J. Limnol. $66: 107-41$.

Hansen, G. \& Daugbjerg, N. 2011. Moestrupia oblonga gen. \& comb. nov. (syn.: Gyrodinium oblongum), a new marine dinoflagellate genus characterized by light and electron microscopy, photosynthetic pigments and LSU rDNA sequence. Phycologia 50:583-99.

This article is protected by copyright. All rights reserved. 
Hansen, G., Daugbjerg, N. \& Henriksen, P. 2000a. Comparative study of Gymnodinium mikimotoi and Gymnodinium aureolum comb. nov. (= Gyrodinium aureolum) based on morphology, pigment composition, and molecular data. J. Phycol. 36:394-410.

Hansen, G., Moestrup, Ø. \& Roberts, K. R. 2000b. Light and electron microscopical observations on the type species of Gymnodinium, G. fuscum (Dinophyceae). Phycologia $39: 365-76$.

Head, M.J. 1996. Modern dinoflagellate cysts and their biological affinities. In Jansonius, J. \& McGregor, D.C. [Eds.] Palynology: Principles and applications. American Association of Stratigraphic Palynologists Foundation, Texas, USA, pp. 1197-284.

Hoppenrath, M., Bachvaroff, T., Handy, S., Delwiche, C. \& Leander, B. 2009. Molecular phylogeny of ocelloid-bearing dinoflagellates (Warnowiaceae) as inferred from SSU and LSU rDNA sequences. BMC Evol. Biol. 9:116.

Hoppenrath, M. \& Leander, B. S. 2007. Morphology and phylogeny of the pseudocolonial dinoflagellates Polykrikos lebourae and Polykrikos herdmanae n. sp. Protist 158:209-27.

This article is protected by copyright. All rights reserved. 
Hoppenrath, M., Murray, S. A., Chomérat, N. \& Horiguchi, T. 2014. Marine benthic dinoflagellates-unveiling their worldwide biodiversity. Kleine Senckenberg-Reihe 54. Senckenberg Geselschaft für Naturforschung, Senckenberganlage, Frankfurt am Main, Germany, $276 \mathrm{pp}$.

Hulburt, E. M. 1957. The taxonomy of unarmored Dinophyceae of shallow embayments on Cape Cod, Massachusetts. Biol. Bull. 112:196-219.

Hulburt, E. M., McLaughlin, J. J. A. \& Zahl, P. A. 1960. Katodinium dorsalisulcum, a new species of unarmored Dinophyceae. J. Protozool. 7:323-26.

Iwasaki, H. 1971. Red tide dinoflagellates-V. On Polykrikos schwartzi Butschli. Bull. Jap. Soc. Sci. Fish. 37:606-09.

Kang, N. S., Jeong, H. J., Moestrup, Ø., Lee, S. Y., Lim, A. S., Jang, T. Y., Lee, K. H., Lee, M. J., Jang, S. H. \& Potvin, E. 2014. Gymnodinium smaydae n. sp., a new planktonic phototrophic dinoflagellate from the coastal waters of western Korea: morphology and molecular characterization. J. Eukaryot. Microbiol. 61:182-203.

This article is protected by copyright. All rights reserved. 
Kang, N. S., Jeong, H. J., Moestrup, Ø. \& Park, T. G. 2011. Gyrodiniellum shiwhaense n. gen., n. sp., a new planktonic heterotrophic dinoflagellate from the coastal waters of western Korea: morphology and ribosomal DNA gene sequence. J. Eukaryot. Microbiol. 58:284-309.

Kang, N. S., Jeong, H. J., Moestrup, Ø., Shin, W., Nam, S. W., Park, J. Y., De Salas, M. F., Kim, K. W. \& Noh, J. H. 2010. Description of a new planktonic mixotrophic dinoflagellate Paragymnodinium shiwhaense n. gen., n. sp. from the coastal waters off western Korea: morphology, pigments, and ribosomal DNA gene sequence. J. Eukaryot. Microbiol. $57: 121-44$

Katoh, K. \& Standley, D.M. 2013. MAFFT Multiple Sequence Alignment Software Version 7: Improvements in Performance and Usability. Mol. Biol. Evol. 30: 772-80.

Kobayashi, S., Kojima, N., Itakura, S., Imai, I. \& Matsuoka, K. 2001. Cyst morphology of a chain-forming unarmored dinoflagellate Gyrodinium impudicum Fraga et Bravo. Phycol. Res. 49:61-5.

This article is protected by copyright. All rights reserved. 
Kofoid, C. A. \& Swezy, O. 1921. The free-living unarmored dinoflagellata. Mem. Univ. Cal. $5: 1-564$.

Kretschmann, J., Filipowicz, N. H., Owsianny, P. M., Zinssmeister, C. \& Gottschling, M. 2015. Taxonomic clarification of the unusual Dinophyte Gymnodinium limneticum Wołosz. (Gymnodiniaceae) from the Tatra mountains. Protist 166:621-37.

Larsen, J. 1994. Unarmoured dinoflagellates from Australian waters I. The genus Gymnodinium (Gymnodiniales, Dinophyceae). Phycologia 33:24-33.

Larsen, J. 1996. Unarmoured dinoflagellates from Australian waters II. Genus Gyrodinium (Gymnodiniales, Dinophyceae). Phycologia 35:342-9.

Li, Z., Oh, S. J., Park, J.W., Lim, W.A. \& Shin, H. H. 2017. Cyst-motile stage relationship, morphology and phylogeny of a new chain-forming, marine dinoflagellate Grammatodinium tongyeonginum gen. \& sp. nov. from Korea. Phycologia 56:429-42.

Moestrup, Ø., Hakanen, P., Hansen, G., Daugbjerg, N. \& Ellegaard, M. 2014. On

Levanderina fissa gen. \& comb. nov. (Dinophyceae) (syn. Gymnodinium fissum, Gyrodinium

This article is protected by copyright. All rights reserved. 
instriatum, Gyr. uncatenum), a dinoflagellate with a very unusual sulcus. Phycologia $53: 265-92$.

Murray, S., De Salas, M., Luong-Van, J. \& Hallegraeff, G. 2007. Phylogenetic study of Gymnodinium dorsalisulcum comb. nov. from tropical Australian coastal waters (Dinophyceae). Phycol. Res. 55:176-84.

Onuma, R., Watanabe, K. \& Horiguchi, T. 2015. Pellucidodinium psammophilum gen. \& sp. nov. and Nusuttodinium desymbiontum sp. nov. (Dinophyceae), two novel heterotrophs closely related to kleptochloroplastidic dinoflagellates. Phycologia 54:192-209.

Posada, D. 2008. jModelTest: phylogenetic model averaging. Mol. Biol. Evol. 25:1253-56.

Qiu, D., Huang, L., Liu, S., Zhang, H. \& Lin, S. 2013. Apical groove type and molecular phylogeny suggests reclassification of Cochlodinium geminatum as Polykrikos geminatum. PloS ONE 8:e71346.

This article is protected by copyright. All rights reserved. 
Reñé, A., Camp, J. \& Garcés, E. 2015. Diversity and phylogeny of Gymnodiniales

(Dinophyceae) from the NW Mediterranean Sea revealed by a morphological and molecular approach. Protist 166:234-63.

Reñé, A., de Salas, M., Camp, J., Balagué, V. \& Garcés, E. 2013. A new clade, based on partial LSU rDNA sequences, of unarmoured dinoflagellates. Protist 164:673-85.

Reñé, A., Satta, C. T., Garcés, E., Massana, R., Zapata, M., Anglčs, S. \& Camp, J. 2011. Gymnodinium litoralis sp. nov. (Dinophyceae), a newly identified bloom-forming dinoflagellate from the NW Mediterranean Sea. Harmful Algae 12:11-25.

Rodriguez, F., Oliver, J., Marin, A. \& Medina, J. R. 1990. The general stochastic model of nucleotide substitution. J. Theor. Biol. 142:485-501.

Ronquist, F. \& Huelsenbeck, J. P. 2003. MrBayes 3: Bayesian phylogenetic inference under mixed models. Bioinformatics 19:1572-74.

This article is protected by copyright. All rights reserved. 
Sampedro, N., Fraga, S., Penna, A., Casabianca, S., Zapata, M., Grünewald, C., Riobó, P. \& Camp, J. 2011. Barrufeta bravensis gen. nov. sp. nov. (Dinophyceae): a new bloom-forming species from the northwest Mediterranean Sea. J. Phycol. 47:375-92.

Schnepf, E. \& Elbrächter, M. 1999. Dinophyte chloroplasts and phylogeny-A review. Grana 38:81-97.

Scholin, C. A., Herzog, M., Sogin, M. \& Anderson, D. M. 1994. Identification of group- and strain-specific genetic markers for globally distributed Alexandrium (Dinophyceae). II. Sequence analysis of a fragment of the LSU rRNA gene. J. Phycol. 30:999-1011.

Spurr, A. R. 1969. A low-viscosity epoxy resin embedding medium for electron microscopy. J. Ultras. Res. 26:31-43.

Stamatakis, A., Hoover, P. \& Rougemont, J. 2008. A rapid bootstrap algorithm for the RAxML Web servers. Syst. Biol. 57:758-71.

Sundström, A. M., Kremp, A., Daugbjerg, N., Moestrup, Ø., Ellegaard, M., Hadju, S. \& Hansen, R. 2009. Gymnodinium corollarium sp. nov. (Dinophyceae)-a new cyst forming This article is protected by copyright. All rights reserved. 
cold-water dinoflagellate from the Baltic Sea; morphology, molecular phylogeny and ecophysiology. J. Phycol. 45:938-52.

Takano, Y. \& Horiguchi, T. 2006. Acquiring scanning electron microscopical, light microscopical and multiple gene sequence data from a single dinoflagellate cell. J. Phycol. 42:251-56.

Takano, Y., Yamaguchi, H., Inouye, I., Moestrup, Ø. \& Horiguchi, T. 2014. Phylogeny of five species of Nusuttodinium gen. nov. (Dinophyceae), a genus of unarmoured kleptoplastidic dinoflagellates. Protist 165:759-78.

Takayama, H. 1985. Apical grooves of unarmored dinoflagellates. Bull. Plankton Soc. Jap. $32: 129-40$.

Tang, Y. Z., Egerton, T. A., Kong, L. \& Marshall, H. G. 2008. Morphological variation and phylogenetic analysis of the dinoflagellate Gymnodinium aureolum from a tributary of Chesapeake Bay. J. Eukaryot. Microbiol. 55:91-9.

This article is protected by copyright. All rights reserved. 
Thessen, A. E., Patterson, D. J. \& Murray, S. A. 2012. The taxonomic significance of species that have only been observed once: the genus Gymnodinium (Dinoflagellata) as an example. PloS ONE 7:e44015.

Wang, N., Luo, Z., Mertens, K. N., McCarthy, F. M. G., Gu, L. \& Gu, H. 2017. Cyst-motile stage relationship and molecular phylogeny of a new freshwater dinoflagellate Gymnodinium plasticum from Plastic Lake, Canada. Phycol. Res. 65: 312-21.

Watanabe, M., Suda, S., Inouye, I., Sawaguchi, T. \& Chihara, M. 1990. Lepidodinium viride gen. et sp. nov. (Gymnodiniales, Dinophyta), a green dinoflagellate with a chlorophyll a-and b-containing endosymbiont. J. Phycol. 26:741-51.

Yuasa, T., Horiguchi, T., Mayama, S. \& Takahashi, O. 2016. Gymnoxanthella radiolariae gen. et sp. nov. (Dinophyceae), a dinoflagellate symbiont from solitary polycystine radiolarians. J. Phycol. 51:89-104.

Zapata, M., Rodríguez, F. \& Garrido, J. L. 2000. Separation of chlorophylls and carotenoids from marine phytoplankton: a new HPLC method using a reversed-phase C8 column and pyridine-containing mobile phases. Mar. Ecol. Prog. Ser. 195:29-45.

This article is protected by copyright. All rights reserved. 


\section{FIGURE CAPTIONS:}

Fig. 1. Micrographs of Wangodinium sinense gen. \& sp. nov. strain G27. A-B, E. Bright-field LM. C, D. Epifluorescence. F. SEM. (A) Ventral view showing the deep sulcal intrusion into the epicone (arrow). (B) Two daughter cells divided through binary fission. (C) Epifluorescence image of several cells in different view. Note the single reticulate chloroplast(Ch) in the periphery of the cell. (D) A SYBR Green-stained cell showing a spherical nucleus $(\mathrm{Nu})$ in the epicone. (E) A cyst produced in culture showing numerous granules. (F) A cyst produced in culture showing the smooth surface. All scale bars $=5 \mu \mathrm{m}$.

Fig. 2. SEM micrographs of Wangodinium sinense gen. \& sp. nov. strain G27. (A) Ventral view showing the deep sulcal intrusion as a narrow furrow and a pronounced ridge in the right epicone. (B) Apical view showing five rows of polygonal vesicles on the epicone (e1-e5). (C) Lateral view showing five rows of polygonal vesicles on the cingulum (c1-c5). (D) Antapical view showing five rows of polygonal vesicles on the hypocone (h1-h6). (E, F)

Details of the apical structure complex, showing two rows of narrow and elongated central ridges $(\mathrm{CR})$ each row comprising 6-7 fragments with numerous small knobs in the inner row of vesicles (arrows) and six or seven irregular amphiesmal vesicles (A1-A7) in the apex. All scale bars $=2 \mu \mathrm{m}$.

This article is protected by copyright. All rights reserved. 
Fig. 3. A schematic drawing of Wangodinium sinense. (A) Ventral view. (B) Dorsal view. (C)

Detail of the apical structure complex showing two rows of amphiesmal vesicles. "A1-A7", "e1-e5", "c1-c5" and "h1-5" indicate apical, episomal, cingular and hyposomal amphiesmal vesicles, respectively.

Fig. 4. TEM micrographs of Wangodinium sinense gen. \& sp. nov. strain G27.

(A) A longitudinal section through the cell in ventral view showing a dinokaryon $(\mathrm{Nu})$ and chloroplast (Ch) with terminal pyrenoids (Py). (B) Detail of the terminal pyrenoid (Py), chloroplast (Ch), and a trichocyst (arrow). (C) Detail of the pyrenoid showing a double envelope (arrows). (D) The nucleus and a rectangular structure with numerous fibrils inside. (E) Detail of the nucleus $(\mathrm{Nu})$ with smooth envelopes. (F) Detail of the outer layers of a cell showing a thin amphiesmal vesicle (Ve). All scale bars $=0.5 \mu \mathrm{m}$, except in $(\mathrm{A})=5 \mu \mathrm{m}$.

Fig. 5. Micrographs of Gymnodinium dorsalisulcum strain TIO09. A. Bright-field LM. B. Epifluorescence. C-F. SEM. (A) Ventral view showing the cingulum in the posterior cell and sulcal intrusion (arrow). (B) A SYBR Green-stained cell showing a round nucleus $(\mathrm{Nu})$ in the epicone. (C) Ventral view showing the apical structure complex (arrows). (D) The same cell in (C) showing the apical structure complex (arrows) and sulcal intrusion (arrowheads). (E) Detail of the apical structure complex showing three rows of elongated vesicles $(*)$ with many small knobs on the outer row of vesicle (arrows). (F) Dorsal view showing the details 
of the apical structure complex comprising two pronounced ridges and a groove inside, with numerous fibrils released from the outer ridge. All scale bars $=5 \mu \mathrm{m}$, except in $(\mathrm{E})=1 \mu \mathrm{m}$.

Fig. 6. TEM micrographs of Gymnodinium dorsalisulcum strain TIO09.(A) A longitudinal section through a cell in ventral view showing a nucleus $(\mathrm{Nu})$, chloroplasts $(\mathrm{Ch})$ and two stalked pyrenoids (Py). (B) A chloroplast showing the thylakoids in twos or threes to form lamellae. (C) Detail of the stalked pyrenoid (Py) showing the surrounding starch sheath (St). (D) Detail of cell wall layers showing amphiesmal vesicles (Ve) and two kinds of extrusomes including mucocysts $(\mathrm{Mu})$ and trichocysts (t). (E) A pusule with an elongated collection tube (arrow) surrounded by many pusular vesicles (arrowheads). (F) Detail of the nucleus showing a nuclear chamber (arrow) and a nuclear pore (arrowhead). All scale bars $=1 \mu \mathrm{m}$, except in $(\mathrm{A})=5 \mu \mathrm{m}$.

Fig. 7. Micrographs of Gymnodinium impudicum strain TIO251. A. Bright-field LM. B-F. SEM.(A) A chain composed of four cells. (B) Detail of the apex showing the pore (arrow) connecting cells. (C) A chain composed of four cells with one of them separated showing the pore in the middle antapex (arrow). (D) Ventral view showing the sulcal intrusion (arrowhead) and the apical structure complex (arrows). (E) Apical view showing the loop-shaped apical structure complex. (F) Detail of the apical structure complex showing three rows of elongated vesicles $(*) .(G)$ Detail of the apical structure complex comprising 
two pronounced ridges and a groove inside with many small knobs on the outer ridge (arrows). All scale bars $=5 \mu \mathrm{m}$, except in $(\mathrm{A}, \mathrm{C})=20 \mu \mathrm{m}$.

Fig. 8. TEM micrographs of Gymnodinium impudicum strain TIO251.(A) A longitudinal section through a cell showing the nucleus $(\mathrm{Nu})$. (B) A transverse section through a cell showing numerous chloroplasts $(\mathrm{Ch})$ in the periphery without a pyrenoid. (C) A pusule with a narrow collection tube (arrow) surrounded by many pusular vesicles (arrowhead). (D) A chloroplast with a double envelope (arrows) and thylakoids in twos and threes to form lamellae. (E) Detail of the nucleus showing a nuclear chamber (arrow). (F) Two kinds of extrusomes including the trichocysts (t) and vesicles with numerous polygonal vesicles (v). All scale bars $=1 \mu \mathrm{m}$, except in $(\mathrm{A}, \mathrm{B})=5 \mu \mathrm{m}$.

Fig. 9. A phylogenetic tree of Wangodinium sinense, Gymnodinium impudicum, and Gymnodinium dorsalisulcum inferred from partial LSU rDNA sequences using Bayesian inference with Noctiluca scintillans as the outgroup. Branch lengths are drawn to scale, with the scale bar indicating the number of the substitutions per site. Numbers on branches are statistical support values to clusters on the right of them (ML bootstrap support /Bayesian posterior probability). Bootstrap values $>50 \%$ and posterior probabilities above 0.7 are shown. * indicates maximal support (ML bootstrap support: 100/ Bayesian posterior probability: 1.00). Dashed lines indicate a half length. Clades are labeled and marked with vertical lines on the right. Schematic drawing of the apical structure complex of 
Wangodinium, Lepidodinium, Barrufeta and Gymnodinium impudicum/dorsalisulcum were shown on the right. New sequences obtained in this study are indicated in bold font.

Fig. S1. SEM micrographs of Wangodinium sinense. (A) Ventral view of strain GBH03. (B) Ventral view of strain GLY03. (C) Detail of apical structure complex of strain G27 showing numerous small knobs (arrows). (D) The sulcus of strain G27 showing five rows of amphiesmal vesicles. All scale bars $=2 \mu \mathrm{m}$.

Fig. S2. Pigment chromatogram of A: Wangodinium sinense strain GBH03, from Beihai, China and B: Gymnodinium dorsalisulcum strain TIO09, from Sanya, China (1: Chlorophyll c3; 2: Chlorophyllide a; 3: Chlorophyll c2; 4: Peridinin; 5: Diadinoxanthin; 6:

Antheraxanthin; 7: Diatoxanthin; 8: Chlorophyll $a$; 9: Pheophorbide; 10: $\beta, \beta$-carotene).

Fig. S3. A phylogenetic tree of Wangodinium sinense, Gymnodinium impudicum, and Gymnodinium dorsalisulcum inferred from partial SSU rDNA sequences using Bayesian inference with Noctiluca scintillans as the outgroup. Branch lengths are drawn to scale, with the scale bar indicating the number of the substitutions per site. Numbers on branches are statistical support values to clusters on the right of them (ML bootstrap support /Bayesian posterior probability). Bootstrap values $>50 \%$ and posterior probabilities above 0.7 are shown. * indicates maximal support (ML bootstrap support: 100/ Bayesian posterior probability: 1.00). Dashed lines indicate a half length. Clades are labeled and marked with vertical lines on the right. New sequences obtained in this study are indicated in bold font.

This article is protected by copyright. All rights reserved. 
Table 1 Strains of Wangodinium sinense, Gymnodinium dorsalisulcum and Gymnodinium impudicum examined in the present study, including origins, collection data and locations

\begin{tabular}{|c|c|c|c|c|c|c|}
\hline Species & Strains & Origins & Collection date & Latitude $\left({ }^{\circ} \mathrm{N}\right)$ & Longitude $\left({ }^{\circ} \mathrm{E}\right)$ & Locations \\
\hline Wangodinium sinense & GLY03 & Sediments & 9 May 2011 & $34^{\circ} 48^{\prime} 46^{\prime \prime}$ & $119^{\circ} 31^{\prime} 38^{\prime \prime}$ & Lianyungang, Yellow Sea \\
\hline W. sinense & $\mathrm{G} 27$ & Sediments & 10 January 2010 & $24^{\circ} 29^{\prime} 49^{\prime \prime}$ & $118^{\circ} 3^{\prime} 42^{\prime \prime}$ & Xiamen, East China Sea \\
\hline$W$. sinense & GBH03 & Sediments & 24 May 2010 & $21^{\circ} 21^{\prime} 11^{\prime \prime}$ & $109^{\circ} 7^{\prime} 11^{\prime \prime}$ & Beihai, South China Sea \\
\hline $\begin{array}{l}\text { Gymnodinium } \\
\text { dorsalisulcum }\end{array}$ & TIO09 & Corals & 16 November 2014 & $18^{\circ} 13^{\prime} 34^{\prime \prime}$ & $109^{\circ} 28^{\prime} 1^{\prime \prime}$ & Sanya, South China Sea \\
\hline G. dorsalisulcum & TIO142 & Seaweeds & 16 April 2015 & $18^{\circ} 17^{\prime} 35^{\prime \prime}$ & $109^{\circ} 44^{\prime} 9^{\prime \prime}$ & Sanya, South China Sea \\
\hline G. dorsalisulcum & SS10H1 & Corals & 17 May 2017 & $5^{\circ} 54^{\prime} 44^{\prime \prime}$ & $102^{\circ} 44^{\prime} 40^{\prime \prime}$ & Perhentian Island, Malaysia \\
\hline G. impudicum & TIO335 & $\begin{array}{c}\text { Plankton } \\
\text { blooms }\end{array}$ & 24 August 2016 & $38^{\circ} 54^{\prime} 44^{\prime \prime}$ & $118^{\circ} 2^{\prime} 3^{\prime \prime}$ & Tianjin, Bohai Sea \\
\hline G. impudicum & TIO251 & Sediment & 18 January 2016 & $42^{\circ} 7^{\prime} 39^{\prime \prime}$ & $9^{\circ} 31^{\prime} 42^{\prime \prime}$ & Corsica, Mediterranean Sea \\
\hline Barrufeta bravensis & DAG8 & & 1 August 2015 & $1^{\circ} 45^{\prime} 2.73^{\prime \prime}$ & $110^{\circ} 18^{\prime} 50.84^{\prime \prime}$ & $\begin{array}{c}\text { Damai Beach, Sarawak, } \\
\text { Malaysia }\end{array}$ \\
\hline
\end{tabular}

This article is protected by copyright. All rights reserved. 
Table 2 Morphological comparisons of Wangodinium sinense to other related species. NA: not available

\begin{tabular}{|c|c|c|c|c|c|c|c|c|c|}
\hline Species & Cell shape & $\begin{array}{l}\text { Cell length } \\
\text { /width }(\mu \mathrm{m})\end{array}$ & Sulcus intrusion & Cingulum & Apical structure complex & Chloroplasts & Nucleus & Resting cysts & References \\
\hline $\begin{array}{l}\text { Wangodinium } \\
\text { sinense }\end{array}$ & $\begin{array}{l}\text { Epicone rounded to } \\
\text { conical, hypocone } \\
\text { rounded. }\end{array}$ & $\begin{array}{l}12-16 \\
/ 10-14\end{array}$ & $\begin{array}{l}85 \% \text { of the } \\
\text { height of the } \\
\text { epicone }\end{array}$ & $\begin{array}{c}\text { Descending, } \\
\text { displacement of two } \\
\text { cingulum widths }\end{array}$ & $\begin{array}{l}\text { Loop-shaped, encircling } \\
\text { around } 80 \% \text { apex }\end{array}$ & $\begin{array}{c}\text { Several, with two } \\
\text { envelopes and } \\
\text { terminal } \\
\text { pyrenoids }\end{array}$ & $\begin{array}{l}\text { Spherical, located } \\
\text { in the epicone, } \\
\text { without nuclear } \\
\text { chambers }\end{array}$ & $\begin{array}{c}\text { Spherical, } \\
\text { with smooth } \\
\text { surface }\end{array}$ & Present study \\
\hline $\begin{array}{l}\text { Gymnodinium } \\
\text { smaydae }\end{array}$ & $\begin{array}{l}\text { Epicone conical, } \\
\text { hypocone rounded. }\end{array}$ & $\begin{array}{l}6.3-10.9 \\
15.1-10\end{array}$ & $\begin{array}{c}2 / 3 \text { of the height } \\
\text { of the epicone }\end{array}$ & $\begin{array}{c}\text { Descending, } \\
\text { displacement of one } \\
\text { cingulum width }\end{array}$ & $\begin{array}{l}\text { Loop-shaped, encircling } \\
\text { around } 80 \% \text { apex }\end{array}$ & $\begin{array}{l}\text { Five to eight, with } \\
\text { stalked pyrenoid }\end{array}$ & $\begin{array}{l}\text { Oval, located in } \\
\text { the anterior part } \\
\text { with nuclear } \\
\text { chambers and } \\
\text { NFC }\end{array}$ & NA & Kang et al. (2014) \\
\hline G. aureolum & $\begin{array}{l}\text { Epicone conical, } \\
\text { hypocone rounded. }\end{array}$ & $\begin{array}{l}14-47 \\
/ 11-43\end{array}$ & $\begin{array}{c}2 / 3 \text { to } 3 / 4 \text { of } \\
\text { the height of the } \\
\text { epicone }\end{array}$ & $\begin{array}{c}\text { Descending, } \\
\text { displacement of two } \\
\text { cingulum widths }\end{array}$ & $\begin{array}{l}\text { Loop-shaped, encircling } \\
\text { apex nearly completely }\end{array}$ & $\begin{array}{l}\text { Numerous } \\
\text { irregular, terminal } \\
\text { pyrenoides }\end{array}$ & $\begin{array}{l}\text { Wider than long, } \\
\text { located in the } \\
\text { equatorial part, } \\
\text { with nuclear } \\
\text { chambers and } \\
\text { NFC }\end{array}$ & spherical & $\begin{array}{l}\text { Hulburt (1957); } \\
\text { Hansen (2001); } \\
\text { Tang et al. (2008) }\end{array}$ \\
\hline G. corollarium & $\begin{array}{l}\text { Epicone conical, } \\
\text { hypocone rounded. }\end{array}$ & $\begin{array}{l}20-31 \\
/ 16-24\end{array}$ & $\begin{array}{l}\text { Deep, nearly } \\
\text { contact the } \\
\text { apical structure } \\
\text { complex }\end{array}$ & $\begin{array}{c}\text { Descending, } \\
\text { displacement of one } \\
\text { cingulum width }\end{array}$ & $\begin{array}{c}\text { Loop-shaped, encircling } \\
\text { apex to } 3 / 4\end{array}$ & $\begin{array}{l}\text { Numerous; } \\
\text { non-peripheral, } \\
\text { radiate from } \\
\text { center with } \\
\text { compound } \\
\text { pyrenoids }\end{array}$ & $\begin{array}{l}\text { Spherical, } \\
\text { beneath the } \\
\text { cingulum with } \\
\text { nuclear chambers }\end{array}$ & $\begin{array}{c}\text { Oval, } \\
\text { transparent } \\
\text { cyst wall, no } \\
\text { surface } \\
\text { structures }\end{array}$ & $\begin{array}{l}\text { Sundström et al. } \\
\text { (2009) }\end{array}$ \\
\hline
\end{tabular}

This article is protected by copyright. All rights reserved. 


\begin{tabular}{|c|c|c|c|c|c|c|c|c|c|}
\hline G. litoralis & $\begin{array}{l}\text { Epicone rounded, } \\
\text { hypocone rounded } \\
\text { and flattened. }\end{array}$ & $\begin{array}{l}19-42 \\
/ 14-37\end{array}$ & Slight & $\begin{array}{c}\text { Descending, } \\
\text { displacement of three } \\
\text { cingulum widths }\end{array}$ & $\begin{array}{l}\text { Loop -shaped, encircling } \\
\text { around } 90 \% \text { apex }\end{array}$ & $\begin{array}{l}\text { Numerous } \\
\text { elongated, located } \\
\text { in the periphery } \\
\text { without pyrenoids }\end{array}$ & $\begin{array}{l}\text { Spherical, in the } \\
\text { epicone, without } \\
\text { nuclear chambers }\end{array}$ & $\begin{array}{c}\text { Smooth. } \\
\text { Round to } \\
\text { oval }\end{array}$ & René et al. (2011) \\
\hline G. & $\begin{array}{l}\text { Epicone conical, } \\
\text { hypocone rounded } \\
\text { and flattened. }\end{array}$ & $\begin{array}{l}34-42 \\
128-42\end{array}$ & $\begin{array}{c}\text { Half of the } \\
\text { height of the } \\
\text { epicone }\end{array}$ & $\begin{array}{l}\text { Descending, } \\
\text { displacement of one } \\
\text { cingulum width }\end{array}$ & $\begin{array}{l}\text { Horseshoe-shaped, } \\
\text { encircling around 90\% } \\
\text { apex }\end{array}$ & $\begin{array}{l}\text { Numerous, } \\
\text { radially arranged }\end{array}$ & $\begin{array}{l}\text { Wider than long, } \\
\text { located in the } \\
\text { equatorial part }\end{array}$ & NA & Biecheler (1952) \\
\hline G. octo & $\begin{array}{c}\text { epicone dome-shaped, } \\
\text { hypocone } \\
\text { wedge-shaped }\end{array}$ & $\begin{array}{l}12-14 \\
17-9\end{array}$ & Deep & $\begin{array}{l}\text { Descending, } \\
\text { displacement of two } \\
\text { cingulum widths }\end{array}$ & $\begin{array}{l}\text { Horseshoe-shaped, } \\
\text { encircling the apex }\end{array}$ & Present & In the hypocone & NA & Larsen (1994) \\
\hline $\begin{array}{l}\text { Lepidodinium } \\
\text { chlorophorum }\end{array}$ & $\begin{array}{l}\text { Epicone conical, } \\
\text { hypocone rounded } \\
\text { and flattened. }\end{array}$ & $\begin{array}{l}18-33 \\
/ 12-18\end{array}$ & $\begin{array}{l}\text { Half of the } \\
\text { height of the } \\
\text { epicone }\end{array}$ & $\begin{array}{c}\text { Descending, } \\
\text { displacement of 1.5-2 } \\
\text { cingulum widths }\end{array}$ & $\begin{array}{l}\text { Loop -shaped, encircling } \\
\text { around } 80 \% \text { apex }\end{array}$ & $\begin{array}{c}\text { Green, lens } \\
\text { shaped to lobed, } \\
\text { internal pyrenoids }\end{array}$ & $\begin{array}{c}\text { Spherical, } \\
\text { centrally located, } \\
\text { with NFC }\end{array}$ & NA & $\begin{array}{l}\text { Elbrächter and } \\
\text { Schnepf (1996) }\end{array}$ \\
\hline $\begin{array}{l}\text { Gyrodinium } \\
\text { impendens }\end{array}$ & $\begin{array}{l}\text { Epicone conical, } \\
\text { hypocone rounded. }\end{array}$ & $\begin{array}{l}20-35 \\
/ 13-19\end{array}$ & None & $\begin{array}{c}\text { Descending, } \\
\text { displacement of two } \\
\text { cingulum widths }\end{array}$ & $\begin{array}{l}\text { Extends from the } \\
\text { proximal end of the girdle } \\
\text { to the apex, following a } \\
\text { sigmoid curve }\end{array}$ & $\begin{array}{l}\text { Several with } \\
\text { pyrenoids }\end{array}$ & $\begin{array}{l}\text { Spherical, located } \\
\text { in the center }\end{array}$ & NA & Larsen (1996) \\
\hline G. vorax & $\begin{array}{l}\text { Epicone conical, } \\
\text { hypocone rounded. }\end{array}$ & $\begin{array}{l}30-35 \\
122-25\end{array}$ & Deep & $\begin{array}{l}\text { Descending, } \\
\text { displacement of three } \\
\text { cingulum widths }\end{array}$ & $\begin{array}{l}\text { Horseshoe-shaped, } \\
\text { encircling around 90\% } \\
\text { apex }\end{array}$ & $\begin{array}{l}\text { Numerous } \\
\text { irregular }\end{array}$ & $\begin{array}{l}\text { Spherical, in the } \\
\text { epicone }\end{array}$ & NA & Biecheler (1952) \\
\hline
\end{tabular}

This article is protected by copyright. All rights reserved. 


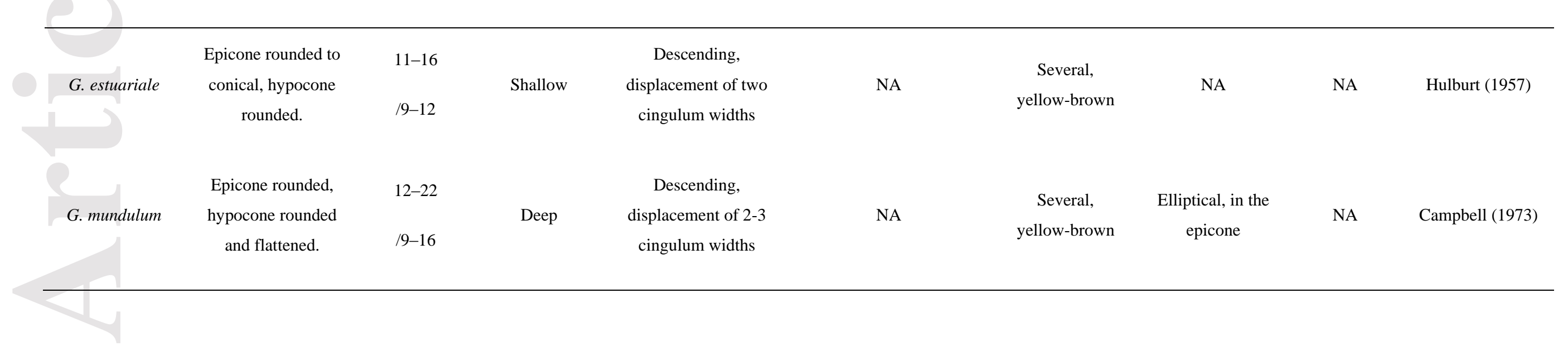

This article is protected by copyright. All rights reserved. 
Table 3 Morphological comparisons of Wangodinium with related genera (NA: not available; NFC: nuclear fibrous connector; type I, II and III refer to an apical structure complex comprising three, one and two rows of amphiesmal vesicles)

\begin{tabular}{|c|c|c|c|c|c|}
\hline Genera & Apical structure complex & Chloroplast & Nucleus & Nematocyst & References \\
\hline Wangodinium & Loop-shaped, Type III & $\begin{array}{c}\text { Enveloped by two } \\
\text { membranes }\end{array}$ & $\begin{array}{l}\text { Nuclear envelope without } \\
\text { vesicular chambers }\end{array}$ & None & Present study \\
\hline Lepidodinium & Horseshoe-shaped, Type I & $\begin{array}{c}\text { Enveloped by two } \\
\text { membranes }\end{array}$ & $\begin{array}{l}\text { Nuclear envelope with } \\
\text { vesicular chambers, NFC }\end{array}$ & None & Hansen et al. (2007) \\
\hline Barrufeta & Smurf-cap shaped, Type I & NA & $\begin{array}{l}\text { Nuclear envelope without } \\
\text { vesicular chambers }\end{array}$ & None & Sampedro et al. (2011) \\
\hline Gymnodinium & Horseshoe-shaped, Type I & $\begin{array}{c}\text { Enveloped by three } \\
\text { membranes }\end{array}$ & $\begin{array}{l}\text { Nuclear envelope with } \\
\text { vesicular chambers, NFC }\end{array}$ & None & Hansen et al. (2000b) \\
\hline Polykrikos & Closed loop-shaped, Type I & $\begin{array}{c}\text { Enveloped by two } \\
\text { membranes }\end{array}$ & $\begin{array}{l}\text { Nuclear envelope with } \\
\text { vesicular chambers }\end{array}$ & Several & $\begin{array}{c}\text { Hoppenrath and Leander } \\
\text { (2007) }\end{array}$ \\
\hline Gyrodiniellum & Loop-shaped, Type II & Absent & $\begin{array}{c}\text { Nuclear envelope } \\
\text { chambers and NFC absent }\end{array}$ & Several & Kang et al. (2011) \\
\hline Paragymnodinium & None & $\begin{array}{c}\text { Enveloped by three } \\
\text { membranes }\end{array}$ & $\begin{array}{c}\text { Nuclear envelope } \\
\text { chambers and NFC absent }\end{array}$ & Several & Kang et al. (2010) \\
\hline Warnowia & $\begin{array}{l}\text { An apical groove spiral } \\
\text { with } 1.5-2.0 \text { turns }\end{array}$ & None & NA & Several & Takayama (1985) \\
\hline
\end{tabular}

This article is protected by copyright. All rights reserved. 

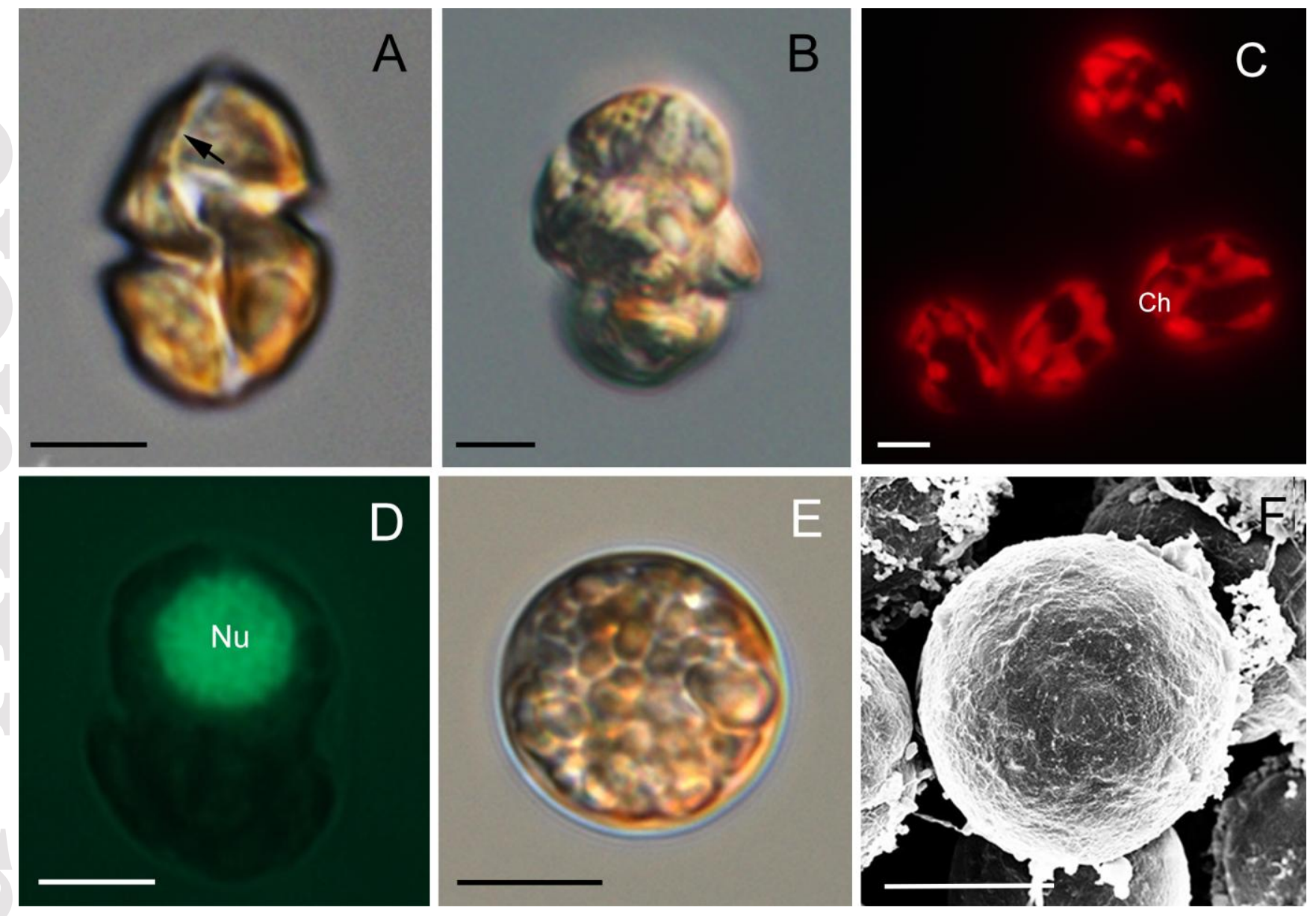

This article is protected by copyright. All rights reserved. 

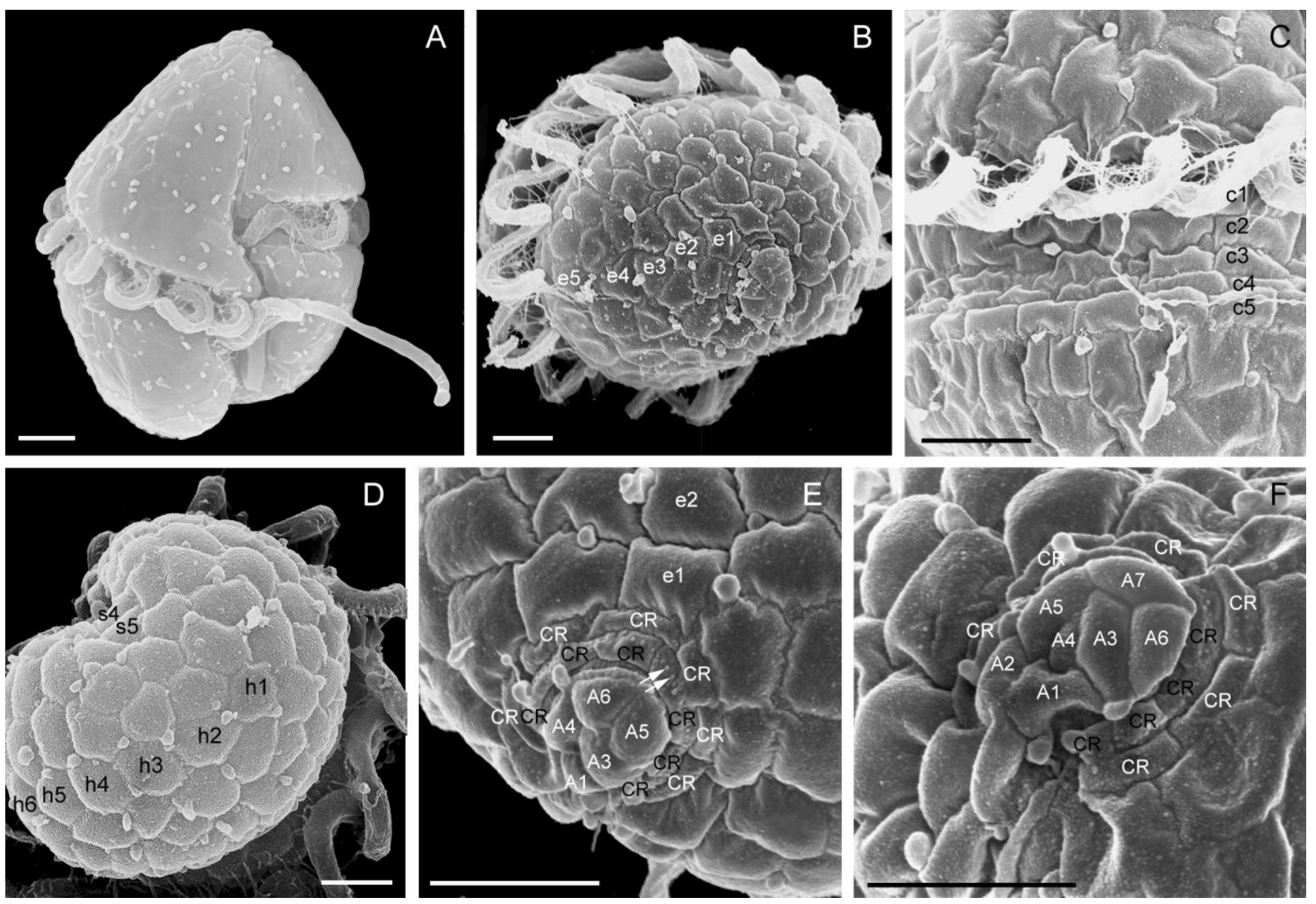

This article is protected by copyright. All rights reserved. 




This article is protected by copyright. All rights reserved. 


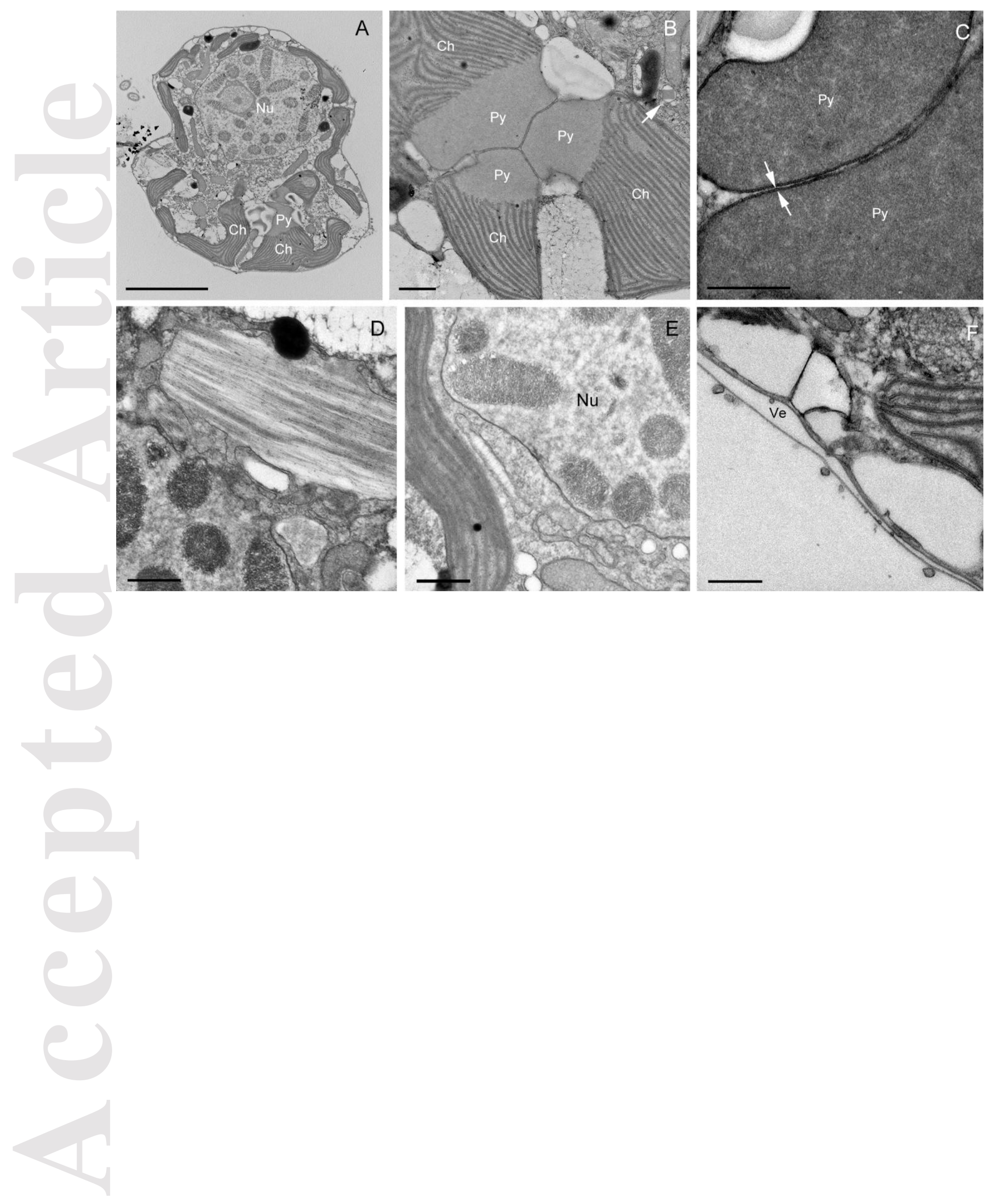

This article is protected by copyright. All rights reserved. 

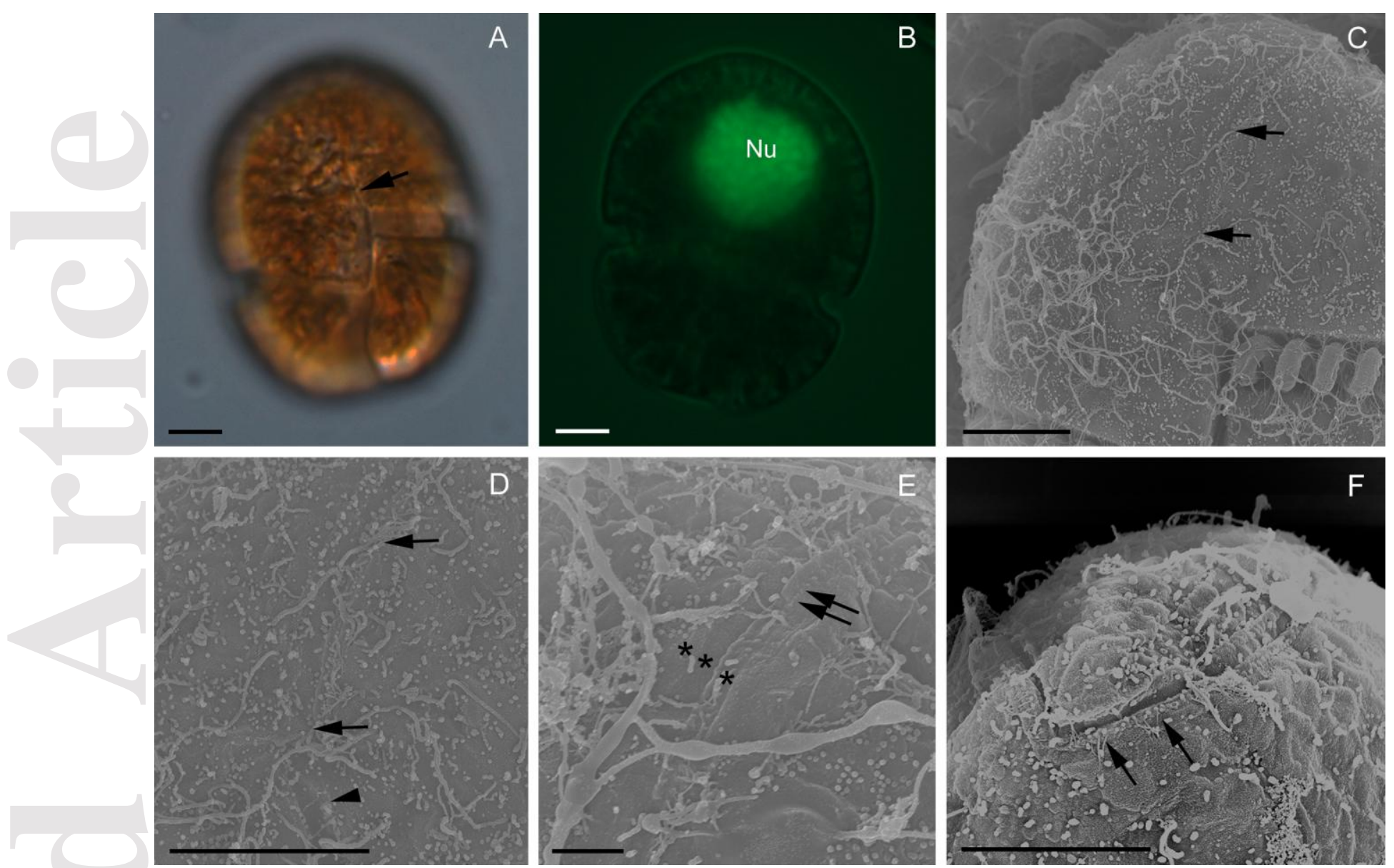

This article is protected by copyright. All rights reserved. 


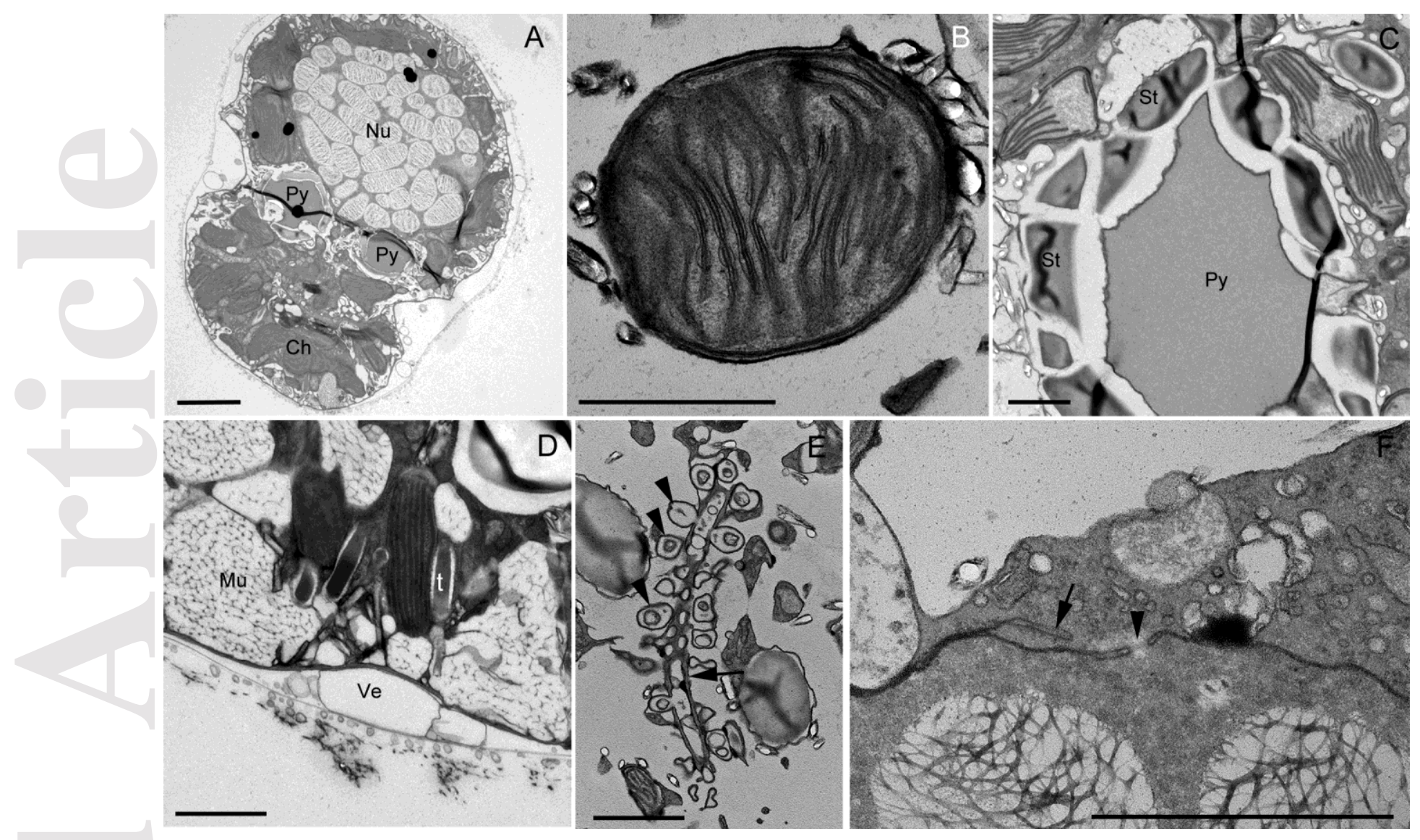

This article is protected by copyright. All rights reserved. 


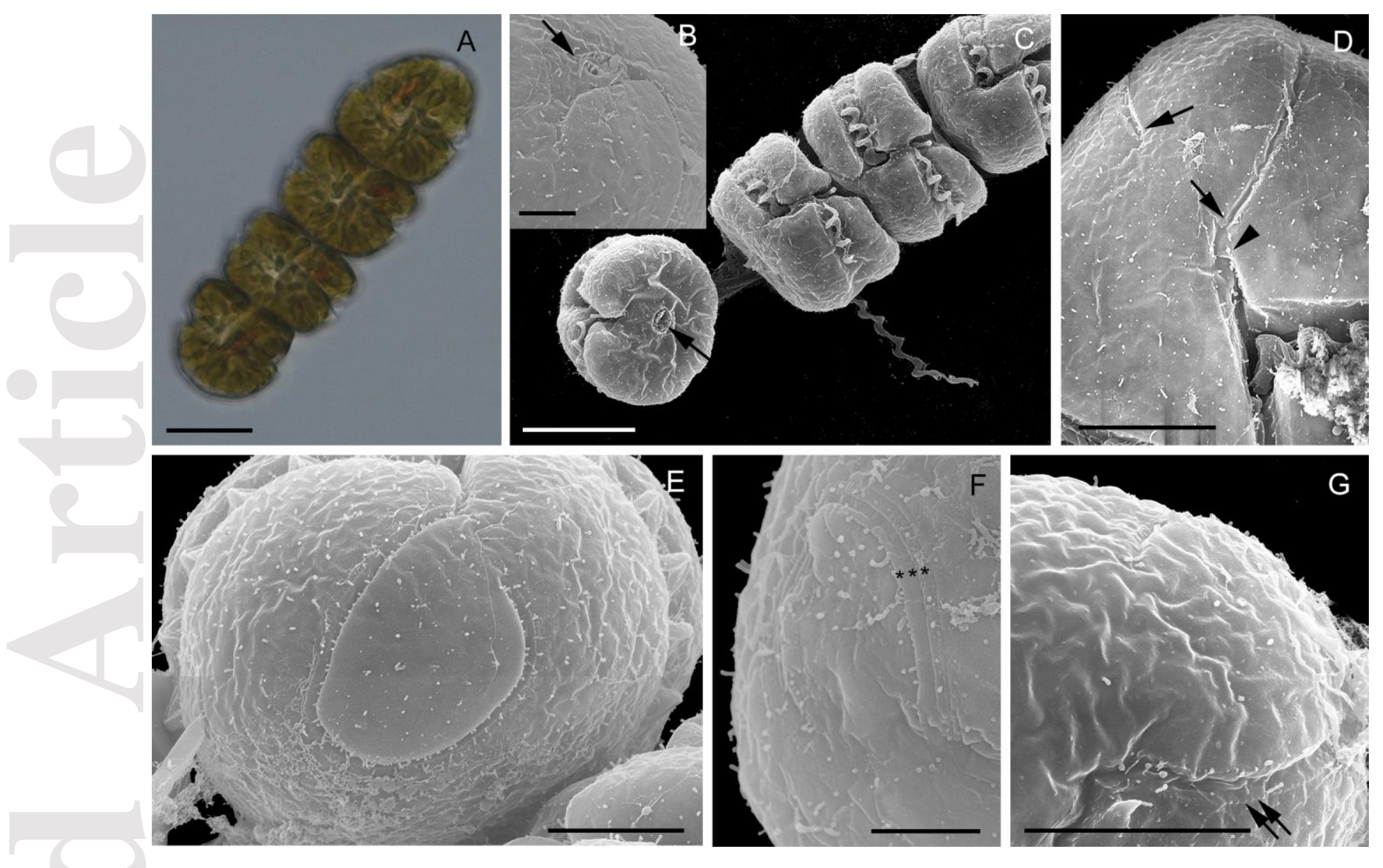

This article is protected by copyright. All rights reserved. 

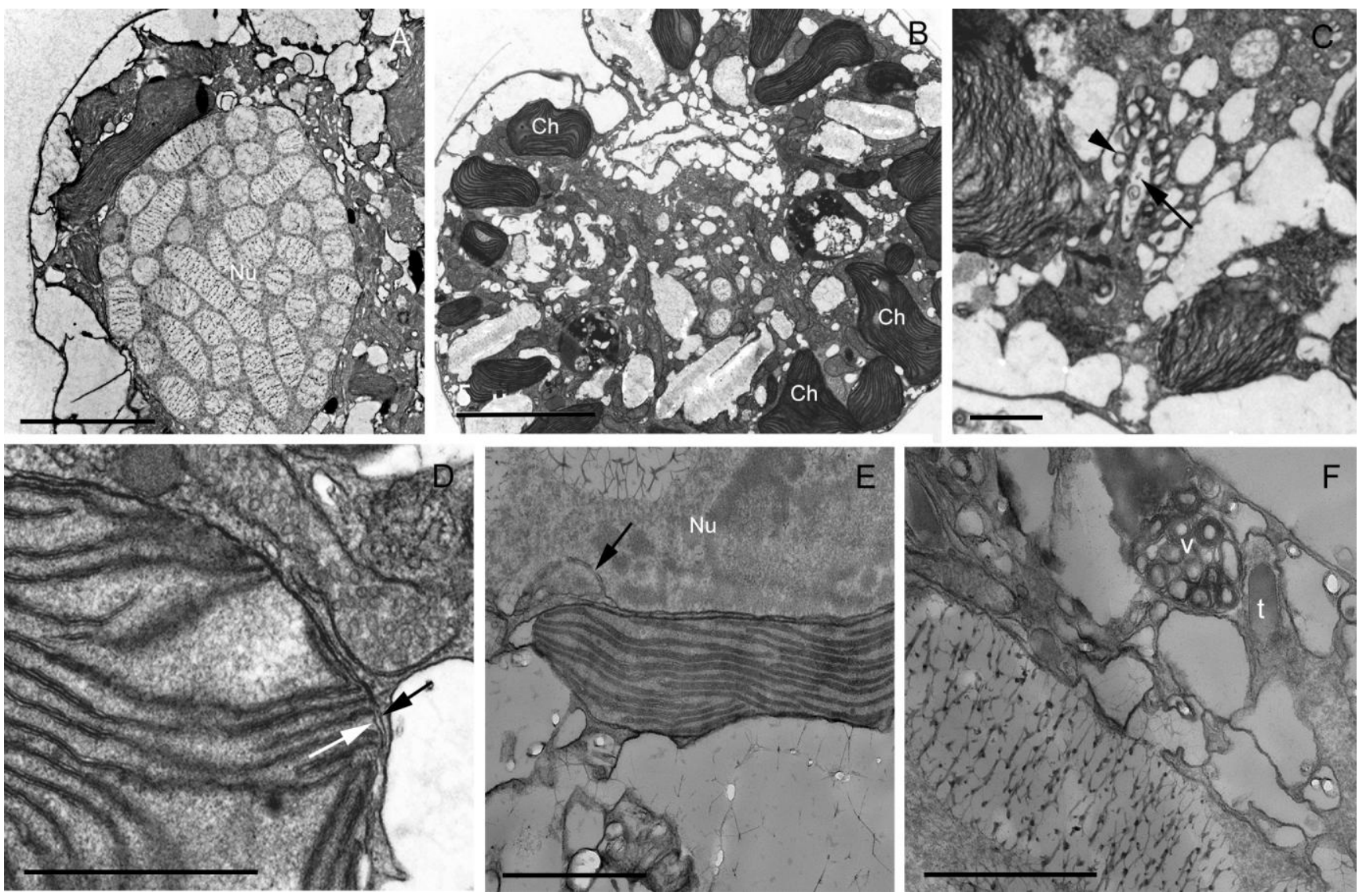

This article is protected by copyright. All rights reserved. 


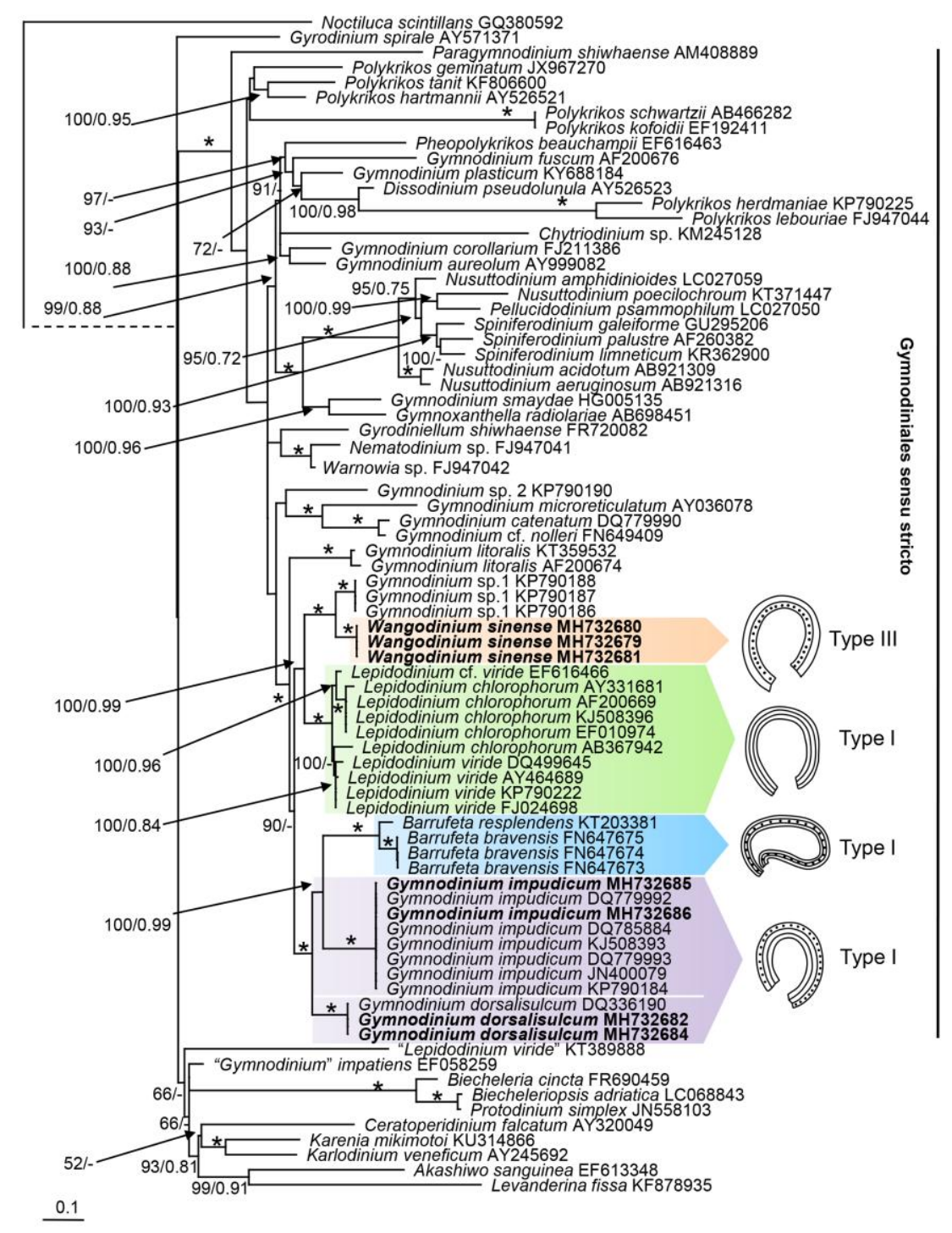

This article is protected by copyright. All rights reserved. 